\section{NGT}

National Institute of Standards and Technology

Technology Administration, U.S. Department of Commerce
Office of Applied Economics

Building and Fire Research Laboratory

Gaithersburg, Maryland 20899

\title{
Guide for Estimating and Reporting Macroeconomic Impacts of MEP Centers
}

Mark A. Ehlen and M. Hayden Brown 


\section{Checklist for Estimating and Reporting Impacts}

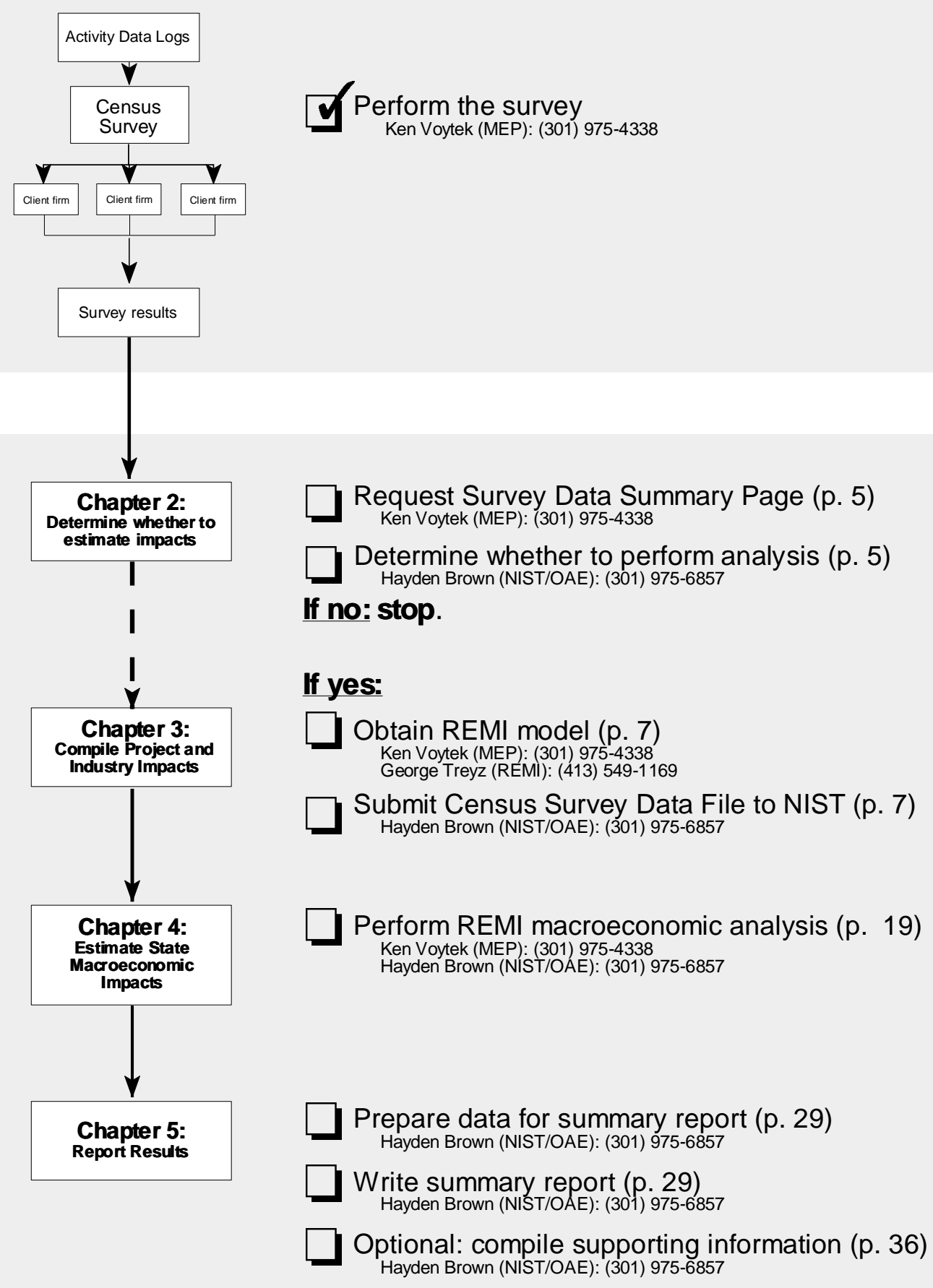


NISTIR 6499

\section{A Guide for Estimating and Reporting the Macroeconomic Impacts of MEP Centers}

Mark A. Ehlen and M. Hayden Brown

May 2000

Prepared for:

Manufacturing Extension Partnership

National Institute of Standards and Technology

Gaithersburg, MD 20899

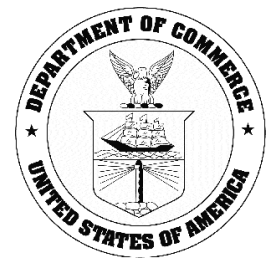

U.S. Department of Commerce

William M. Daley, Secretary

Technology Administration

Dr. Cheryl L. Shavers, Under Secretary for Technology

National Institute of Standards and Technology

Raymond G. Kammer, NIST Director 



\section{Table of Contents}

Chapter 1:

About this Guide

1.1 Purpose

1.2 Topics covered

1.3 Who should read this guide

Chapter 2:

Determine Whether To Estimate Impacts

Chapter 3:

Compile Project and Industry Impacts

3.1 The Census Follow-up Survey Data File

3.2 The NIST Data Processor

3.3 Identify and select impacts

3.4 Perform inflation and annualizing adjustments

$\begin{array}{ll}\text { 3.5 Adjust labor, material, and inventory impacts } & 11\end{array}$

3.6 Adjust sales impacts

3.7 Adjust jobs (created and retained) impacts

3.8 Adjust investment impacts

3.9 Conclusions

Chapter 4:

Estimate State Macroeconomic Impacts

4.2 Run a REMI simulation of state impacts

Chapter 5:

Report Results

5.1 Determine the best format for reporting results

5.2 Make the two-page summary report

5.3 Explain the two-page summary report

5.4 Further explain the results

\section{Appendix A:}

Federal, state, and local tax revenues as a percent of personal income

The REMI 14-sector classification, with two-digit-SIC manufacturing detail

BLS and REMI Data

Depreciation schedule for capital investment 
Disclaimer:

Certain trade names and company products are mentioned in the text or identified in an illustration in order to adequately specify the experimental procedure and equipment used. In no case does such identification imply recommendation or endorsement by the National Institute of Standards and Technology, nor does it imply that the products are necessarily the best available for the purpose. 


\section{About this Guide}

\subsection{Purpose}

Manufacturing extension centers must often report on the impacts they have had on their client firms. The main data source of these impacts is the survey of Manufacturing Extension Partnership (MEP) clients, which interviews MEP client firms to see how their performance has changed as a direct result of center services. The 1999 MEP publication A Guide for Communicating Impact[10] suggests numerous ways to report these direct, client-reported impacts to center stakeholders.

Another impact that the Guide suggests reporting is the macroeconomic impact an MEP center has on the state economy. By "macroeconomic impact" we mean the total effect on the entire state economy, such as on state aggregate output, employment, personal income, and tax revenues. The total effect is the sum of the direct effect of the client-reported impact-appropriately adjusted—plus its indirect effect on the rest of the state economy. For example, if a client firm increases its sales and this increases production in the state, the new production creates demand for other firms' production-similar to how new machine-tool production creates new demand for raw steel—and the combined new production creates additional jobs, income, and spending. This estimate of total impact, of course, depends on the client-reported impacts: if these reported impacts are a complete measure of the direct economic impact of a center, then the estimates of state macroeconomic impact are also complete.

Clearly, however, there are limitations to this method. First, the client survey is by no means a measure of all direct impacts; many are not captured in the survey. Second, the tools available for modeling firm-level impacts and generating estimates of state-wide impacts are imperfect. Both measures are, at best, only estimates. Still, these quantitative estimates of macroeconomic impact are very useful for center evaluation.

At least three tools are available to centers for modeling and estimating the state macroeconomic impact of client-reported impacts, ranging from the simplistic to the more valid and reliable:

\section{Multipliens}

Multipliers are single numbers, such as " 2.5 ," which estimate the total impact on the state economy of a change in one of its sectors. If sales in one manufacturing industry increase by $\$ 1$ million and the industry's sales multiplier is 2.5 , then applying the multiplier yields an estimated increase in total state sales of $\$ 2.5$ million ( $\$ 1$ million $\mathrm{x}$ 2.5). Multipliers for national and regional economies can be obtained from a number of sources, most notably the Bureau of Economic Analysis[12]. Multipliers are easy to use, but simplistic. They do not estimate inter-industry effects, such as the effect of a change in manufacturing output on non-manufacturing sectors. They also do not estimate how impacts vary over time; that is, they are static measures of impact. For these reasons, some center stakeholders may require a more comprehensive and defensible modeling approach. 


\begin{abstract}
Input-Output Models
Input-output (I/O) models expand upon the concept of multipliers. Not only can I/O models compute the total effect on the state economy of a change to one or more manufacturing sectors, but they can also estimate the effect on other, nonmanufacturing sectors and on consumers. To do this, they use a matrix of relationships between industrial and consumer sectors. IMPLAN[7] and RIMS II[12] are two widely used I/O models available at reasonable prices. While more defensible than multipliers, I/O models are still static, that is, they measure the one-time effect of a one-time economic change.
\end{abstract}

\title{
Dynamic Macroeconomic Models
}

Dynamic macroeconomic models combine I/O models, economic theory, and econometrically-estimated, time-dependent equations to model year-to-year changes in the economy. If client-reported sales in one industry increase from $\$ 250,000$ to $\$ 1$ million over a four-year period, dynamic macroeconomic models can model the yearto-year inter-industry and total state impacts of these client sales over the four-year period and beyond. Dynamic models can be used to estimate multipliers and the industry and consumer impacts computed in I/O models. REMI[9], DRI-McGraw[1], and WEFA[15] are dynamic models available in various forms, ranging from inexpensive simulations executed by the model's developers to consulting services and outright purchases of the models. Analyses based on dynamic models are considered to be among the most comprehensive and defensible approaches available.

As one moves from simplistic multipliers to complex dynamic models, the richer and more precise the analysis is and the more defensible the results are. Models of increasing sophistication can, however, complicate the process of estimating impacts and interpreting and reporting results and can increase the time spent by a center for the analysis.

The NIST Office of Applied Economics (OAE), in support of MEP, has developed a process for using one of the dynamic macroeconomic models available, REMI, to estimate and report the state macroeconomic impacts of the client impacts reported in the client survey. This step-by-step process is designed to be time-efficient and affordable. Centers in Alabama, California, Illinois, Kentucky, New York, Ohio, Pennsylvania, Tennessee, and Texas have worked with the NIST OAE to test and refine this process. This Guide for Estimating and Reporting Macroeconomic Impacts of MEP Centers describes the NIST-developed process in detail.

The Guide is designed to use client survey data derived from the Census Follow-up Survey[8], employed by MEP from 1995 to 2000. A new survey instrument was started in 2000, replacing the Census Survey. The Guide can be applied to data from the new survey, with appropriate modifications to the methodology described in Chapter 3. For clarity, however, the Guide only describes using the Census Survey data.

The NIST-developed process generates industry-impact data that, in general, could be used with multipliers, input-output models, and dynamic macroeconomic models other than REMI. For clarity and best practice, however, this guide is tailored to help centers specifically use REMI to estimate and report state impacts in a defensible, efficient, and cost-effective manner. 
This guide provides

- a set of criteria for assessing whether your center has sufficient Census Follow-up Survey data to estimate state macroeconomic impacts;

- a step-by-step process for compiling client-reported impacts in an automated fashion and estimating state macroeconomic impacts;

- a sample two-page summary report that describes the Census Survey results and your estimates of state macroeconomic impacts; and

- supporting information to strengthen your presentation of the results in the summary report.

\subsection{Topics Covered}

This guide is organized to make estimation and reporting both efficient and accurate. The step-by-step process will help you:

- Determine whether to proceed with estimation (Chapter 2). Before investing time, money, and other center resources on extensive analysis, a center should determine whether it has sufficient data (1) to lessen the effect of errors in how clients report impacts; and (2) to generate large impacts.

- Compute client-reported impacts and industry impacts required for modeling macroeconomic impacts in REMI (Chapter 3). The results of the Census Follow-up Survey are returned to a center in a form that is not amenable to either computation of client impact totals or use in macroeconomic modeling. An automated process developed at NIST quickly and correctly computes project-impact totals and adjusts them so they can be used in REMI.

- Run an analysis using the REMI model (Chapter 4). This guide assumes that a center does not own a macroeconomic model in-house and will use a third-party-such as an outside contractor, an agency in its state, or the model's developer-to perform the analysis. So that you remain informed about each step, the guide explains how a REMI simulation is performed, from input of the data to simulation and viewing of the results. Still, sufficient detail is given so that centers that have REMI in-house can perform their own simulations.

- Report the analysis results in a two-page summary (Chapter 5). Once macroeconomicimpact estimation is complete, the results need to be reported in a way that is easy for center personnel to understand and, most importantly, deliver and explain to their stakeholders. This guide suggests a two-page summary report and provides supporting information for informed and defensible reporting.

Use the checklist on the inside cover as a guide in completing these steps. 


\subsection{Who Should Read This Guide}

This guide is specifically written for center personnel who need to estimate and report the state macroeconomic impacts of their client-reported impacts. These personnel include:

- Center directors who need to understand and describe to their stakeholders the state impacts of their center;

- Evaluation staff who need to estimate and report the state impacts of center projects; and

- Center strategic planners who need to understand the state economy so that the center can better address the needs of the manufacturing industry in the state.

Because the macroeconomic impact simulations can be performed by REMI (the company), by another in-state agency that has the REMI model, or by you (as a REMI licensee), this guide explains estimation and reporting in the context of each of these scenarios. If you are only overseeing one or more of the steps, the guide provides enough detail so that you can both monitor analysis and have sufficient information about it to support the presentation of your results. If, on the other hand, you are performing most of the analysis yourself, the guide provides explicit mathematical formulas and other modeling details so that you can perform the analysis correctly. 


\section{Determine Whether to Estimate Impacts}

Estimating the state macroeconomic impacts of client-reported sales and other impacts is a multi-step process. Because dynamic macroeconomic models such as REMI estimate the effect of an industry on all other parts of the economy, one must first convert the Census Follow-up Survey client-level impacts to industry-level impacts. Once industry impacts are computed, REMI can estimate total state impacts.

Converting client-reported impacts to industry impacts and then to state impacts takes expertise, time, and center resources. Before starting estimation, then, one should be relatively certain that the analysis will be successful, that is, the results will be defensible and of sufficient magnitude to be worth reporting. Two criteria are offered here as indicators of potential success:

- To be a defensible analysis, there should be a sufficient number of projects so that errors in reporting by client firms tend to average out. The larger the number of projects in the analysis, the smaller the effect of this reporting error will be.

- To yield macroeconomic impacts that suggest a center is at least fiscally neutral, there should be sufficient client-reported impacts such that, after macroeconomic analysis, the increase in state and local tax revenues is worth reporting.

To determine whether you have projects and impacts that satisfy these criteria, first request from MEP the Survey Data Summary Page for your center, a sample of which is shown in Figure 1. Next, compare the total number of projects, sales impacts, jobs impacts (created plus retained), and capital investment impacts listed in this summary to their suggested-minimum counterparts in Table 1. If the values from your Summary Page are all larger than the minimums listed in Table 1, reporting errors will be reduced and analysis of your project data will likely generate tax revenue estimates worth reporting.

It is possible, however, that your data will not meet one or more of the criteria in Table 1. In this case, since the criteria are an indicator of success rather than the basis of a rigid "go or no-go" decision, a judgement call can be made, based on which of your data satisfy the criteria and by how much. Since there are trade-offs between the impact types, an impact type that is less that the required minimum can be offset by another impact type that exceeds its minimum requirement. Here are some suggestions:

If your data have fewer than the suggested minimum number of projects or fewer than the minimum sales, you should probably postpone analysis until you have additional surveyed projects and impacts.

If your data have fewer than the minimum jobs or capital investment listed but your sales impacts are $\$ 15$ million or more (per \$1 million in annual center funding), macroeconomic analysis should generate impacts of sufficient magnitude to be worth reporting. 


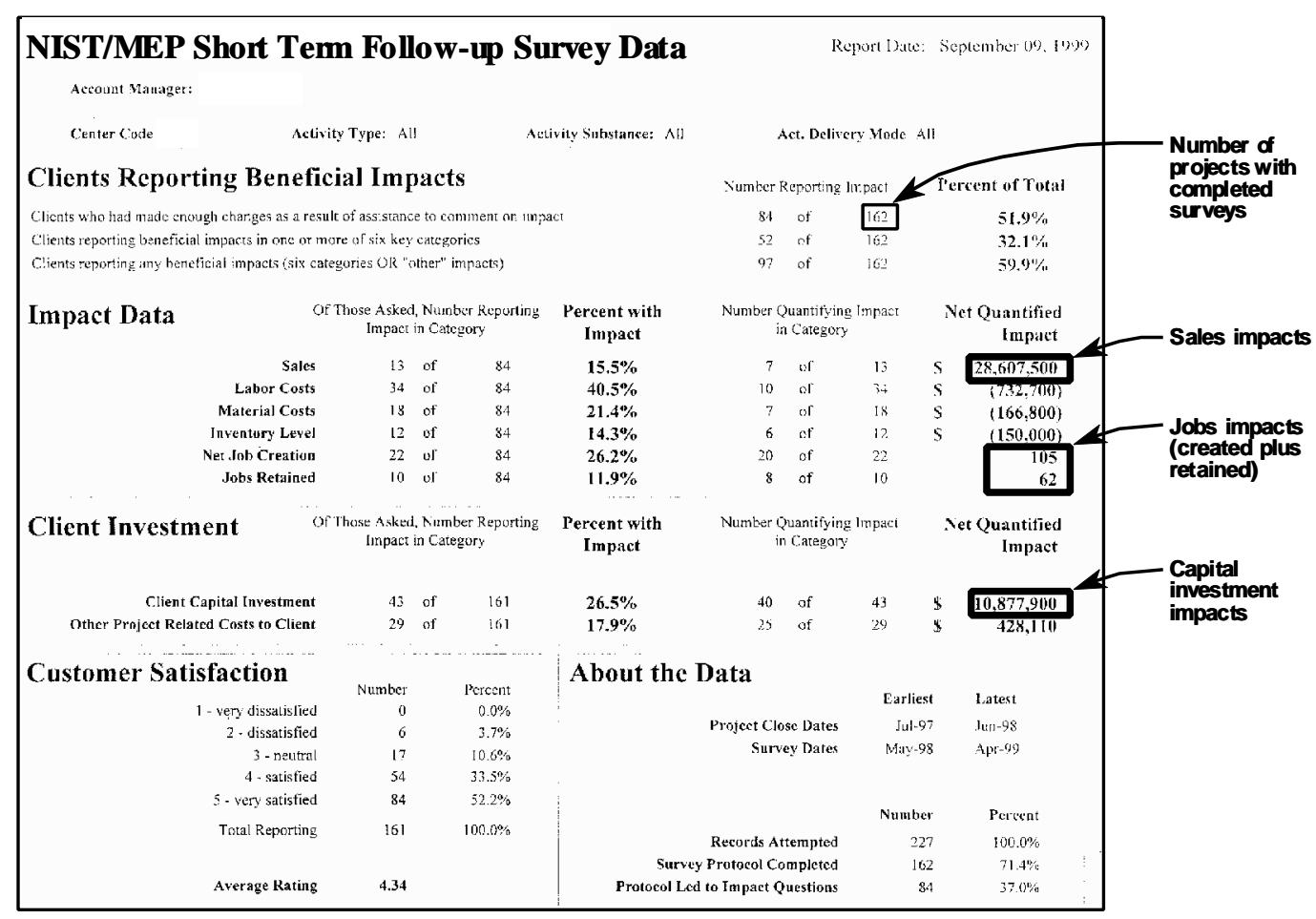

Figure 1. Survey Data Summary Page

Table 1. Criteria for Conducting Analysis

Item

Minimum

Number of projects with completed surveys

Value

Client-reported economic impacts

Sales Impacts

$\$ 10$ million

(per \$1 million in center funding for period covered)

(created plus retained, per $\$ 1$ million in center funding for period covered)

Capital Investment Impacts

(per \$1 million in annual center funding for period covered)

\$6 million 


\section{Compile Project and Industry Impacts}

Now that you have decided to proceed with the macroeconomic analysis, you need to prepare for it. The checklist in Table 2 describes the process of getting ready to estimate macroeconomic impacts using your Census Follow-up Survey data and the REMI model.

Table 2. Preparation Checklist

Obtain access to the REMI model of your state. Either have REMI (the company) run the impact simulation for you, have another agency in the your state run the simulation, or lease the REMI model.

$\square$ Provide NIST with the Census Follow-up Survey Data File for your state center(s). This is the file that the Census Bureau provides to each center.

Provide NIST with select REMI baseline-forecast data. If you are having REMI (the company) run your impact simulation, they will provide this data to NIST. If you own the REMI model, you will need to send the data to NIST, using the method described in Appendix B.

After you have completed these three steps, NIST is ready to use the NIST Data Processor to compile project and industry impacts for the REMI model. The NIST Data Processor is a software program written and maintained by NIST that generates two analysis files:

- The NIST Data Report. This is a text file that lists summary statistics for use in the two-page summary report (see Section 5.2).

- The NIST REMI Input File. This file contains all the project impacts for your state, appropriately adjusted by the NIST Data Processor and ready for input into REMI. The impacts are in the form of REMI policy input variables. If you are having REMI (the company) or another agency run your macroeconomic simulations, they will use this file (you will also receive a copy of it). If you own the REMI model yourself, you will import the NIST REMI Input File in the REMI model (see Section 4.2).

The following sections describe how the Census Follow-Up Survey Data are converted by the NIST Data Processor into industry level impacts, and the form in which they are output.

\subsection{The Census Follow-up Survey Data File}

Each center maintains an activity data $\log$ (ADL) of the projects they have had with client firms. MEP collects these data and submits them to Census, which then interviews each firm by telephone. The combined ADL and survey responses-the Census Follow-up Survey data-are then sent to MEP.

The following sections describe how the NIST Data Processor takes data from a Census Follow-up Survey data file and converts them to REMI inputs. These inputs are used in the macroeconomic impact simulation of client-reported impacts. 


\subsection{The NIST Data Processor}

The Office of Applied Economics at NIST has developed a computer algorithm called the "NIST Data Processor" which compiles data from the Census Follow-up Survey and prepares it for use in the REMI model. Table 3 lists the steps performed by the NIST Data Processor. All of these steps are applied to quantified project impacts except jobs impacts (created and retained), which do not require the adjustment for inflation (in step 2).

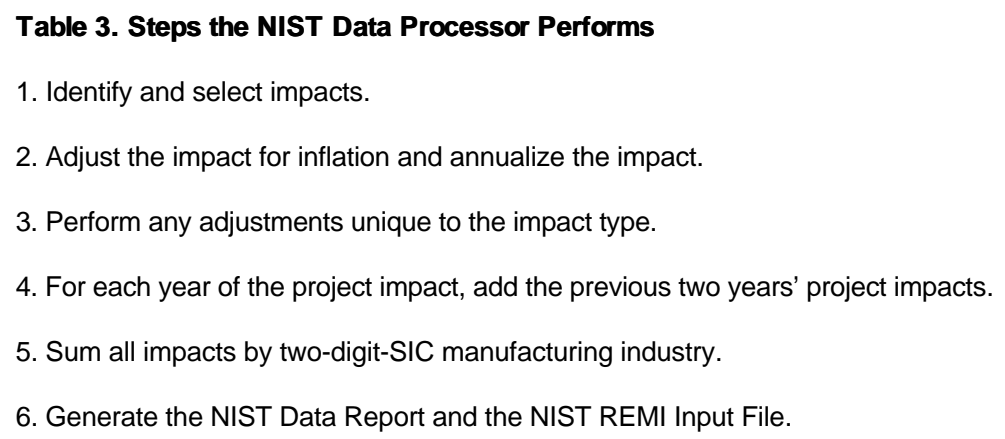

The following sections explain these and other specific adjustments that the NIST Data Processor performs. Each section addresses two questions:

- What steps need to be done?

- Why do these steps need to be done?

All operations are done on each individual project record in the Census Follow-up Survey Data File. The NIST Data Processor then gathers and consolidates these adjusted impacts, at the two-digit level of the Standard Industrial Classification (SIC) Manual.

\subsection{Identify and Select Impacts}

The NIST Data Processor first identifies projects that have incomplete surveys and drops them. Incomplete surveys result when firms cannot be reached, and also when they cannot provide impact quantities.

Next, the NIST Data Processor identifies which projects report impacts. A project may have any combination of the following impacts: change in sales, change in jobs, capital investment, materials cost savings, labor cost savings, and inventory reduction. Due to the set of questions in the Census Followup Survey data, it is possible for these impacts to exist without a corresponding quantity. For example, a firm may respond that jobs increased but not specify by how much. Therefore, the NIST Data Processor must also confirm that there is a quantity for every reported impact. Only impacts with a reported, nonzero quantity are used in analysis.

The NIST Data Report lists how many projects it dropped due to an incomplete survey. It also tells you how many projects had positive impacts that could not be included in the analysis because the firm did 
not indicate a quantity.

\section{Why All Impacts are Not Used}

The NIST Data Processor uses an impact preference hierarchy to select the impacts that will be adjusted and analyzed. Three of the impacts are easy to deal with since they are generally not related in an economic manner: materials cost savings, labor cost savings, and inventory reduction. For example, if a firm reduces the amount of product in inventory, the same firm will not necessarily reduce labor or materials cost. Therefore, the change in materials cost, labor cost, and inventory cost may all be used together when they occur in the same project. Quantified materials cost savings, labor cost savings, and inventory reduction are always used when they are present in a project.

The other three types of impacts—sales, jobs, and investment—are, however, related in an economic manner. For example, a firm that has a sales increase will often need more employees. Or perhaps a firm re-tools a production line (investment) or hires more employees with the intent of increasing sales. Said another way, a firm is likely to see correlated changes in sales, jobs, and investment. In order to avoid double- or triple-counting of client-reported impacts, the NIST Data Processor uses an impact preference hierarchy to select which impact—sales, jobs, or investment—should be included in the analysis and to what extent.

\section{Select Preferred Impact}

Figure 2 illustrates the impact preference hierarchy used by the NIST Data Processor to select the preferred impact of a project that has any combination of sales, jobs, and investment impacts. 


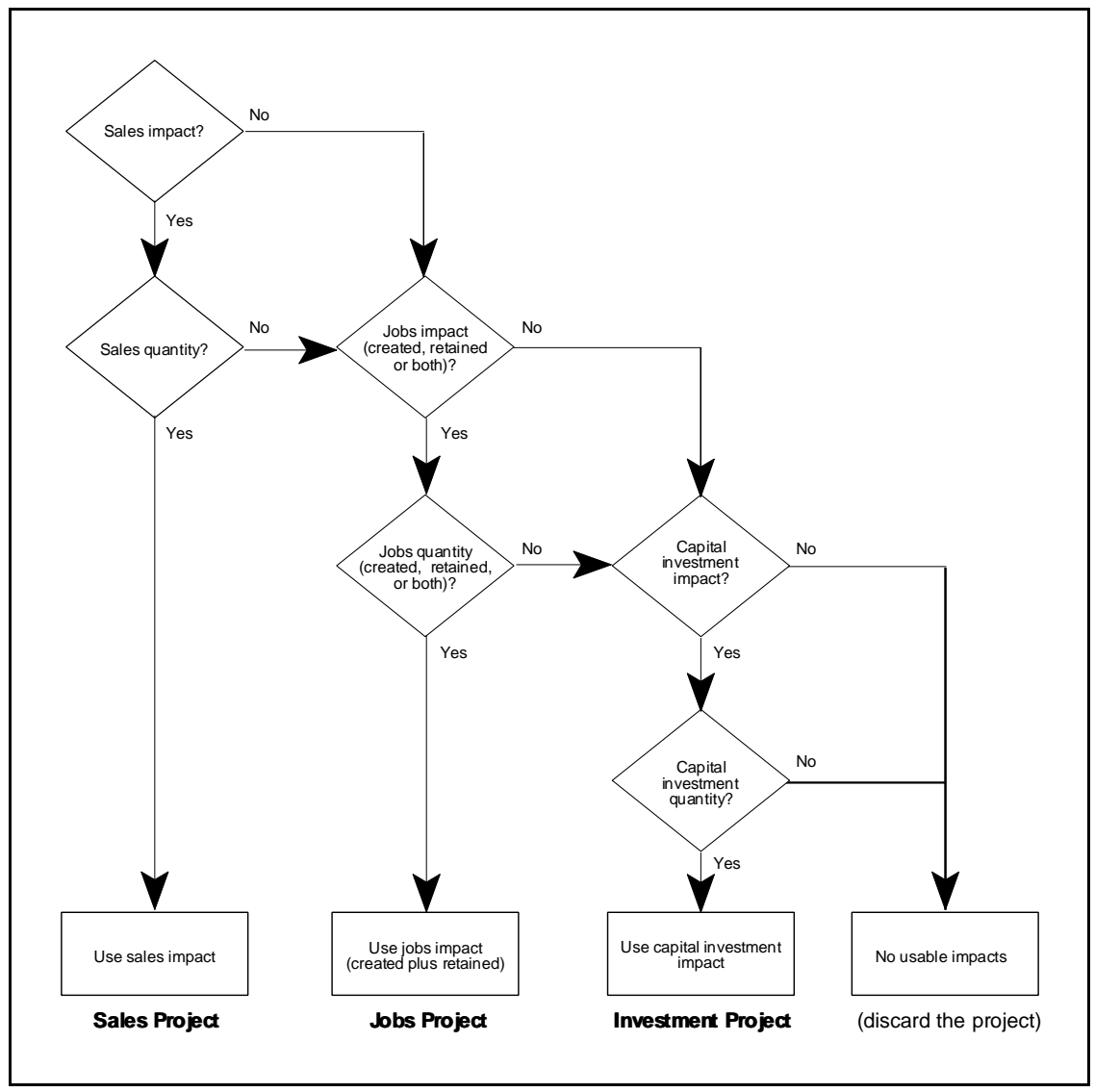

Figure 2. Impact Modeling Decision Tree: Sales, Jobs, and Capital Investment Impacts

If a project reports a nonzero sales impact, then the project is classified as a "sales project" and only the sales impact is used. A sales impact is likely to be the initial change that a typical firm sees as a result of MEP assistance. The NIST Data Processor analyzes sales first and if a project has a usable sales quantity, any reported change in jobs or investment in the same project is ignored. If a project reports zero sales impact but nonzero jobs impact, then the project is classified as a "jobs project;" the jobs impact is used and any investment impact is ignored. If the project reports zero sales and jobs impacts but nonzero investment impact, then the project is classified as an "investment project" and investment impact is used. Investment has an indirect, long-term effect on production; care has been taken in modeling this change in REMI.

\subsection{Perform Inflation and Annualizing Adjustments}

Dollar-denominated project impacts are assumed to be reported in nominal dollars, that is, in values based on the prices in the year the impacts occurred. Because of inflation-the change in prices from year to year-nominal-dollar amounts from different years should not be compared or combined. To correct for inflation, the NIST Data Processor uses a price index to convert nominal dollar amounts to constant dollars. For each project, the NIST Data Processor identifies the year the project was surveyed. Then it adjusts dollar-denominated reported impacts using that year's price index, which is obtained from the REMI baseline forecast. 
The NIST Data Processor calculates the reporting period, the time between project end date and project survey date, and assumes that project impacts occur uniformly over the period. It next calculates the fraction of the reported impact occurring in each calendar year. In this annualizing adjustment, each year's share of the impact is determined by the number of days the impact lasted in that year. Figure 3 illustrates how the NIST Data Processor performs the annualizing adjustment on a hypothetical impact that has an 18-month reporting period.

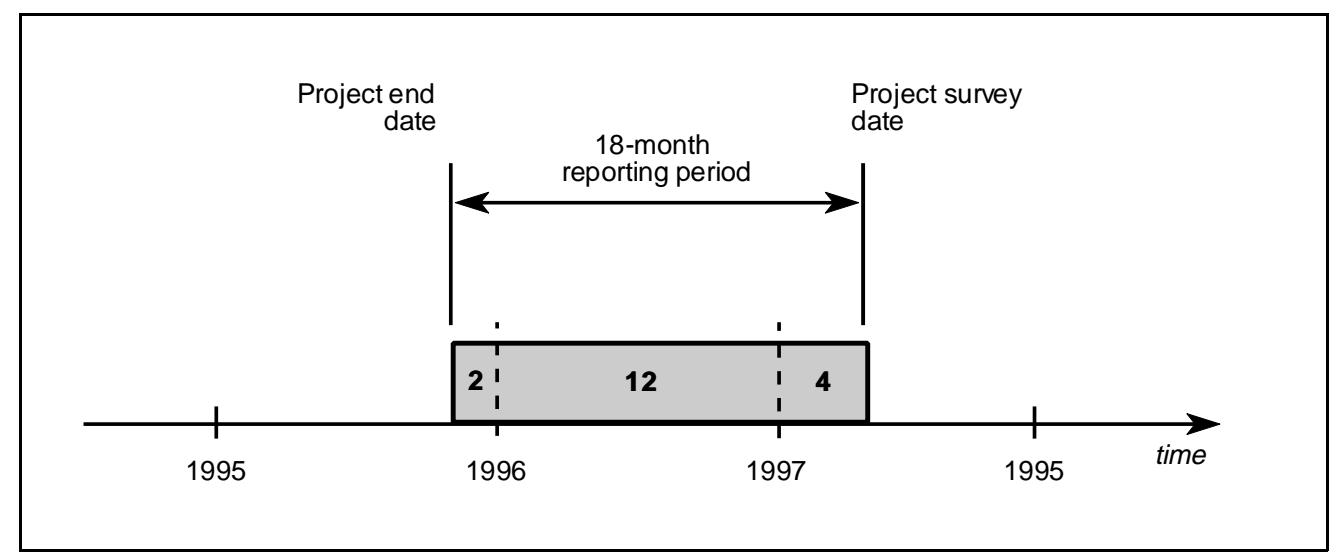

Figure 3. Annualizing Adjustment of a Client-Reported Impact

The first 2 months of the impact occur in 1995, the next 12 months occur in 1996, and the last 4 months occur in 1997. Therefore, $11 \%$ of the reported impact is assumed to occur in $1995,67 \%$ in 1996, and 22\% in 1997. The NIST Data Processor performs this annualizing adjustment on every impact.

There are several benefits to this approach. First, impacts are precisely allocated to the year in which they are assumed to occur. Second, impacts that last more than one year do not cause overestimation of macroeconomic impacts. Third, the macroeconomic analysis is not restricted to 12 months of data. The NIST Data Processor takes advantage of REMI's ability to model impacts over time by allocating impacts to the year(s) in which they occurred.

\subsection{Adjust Labor, Material, and Inventory Impacts}

All projects with usable labor cost or material cost values have a positive or negative dollar amount of cost change in one or both categories. Usually these values are negative, indicating that costs decreased. All projects with a usable inventory change have a positive or negative dollar amount of change in the total value of product in inventory. Generally, this value is negative, indicating that inventory decreased.

The material cost change, the labor cost change, and one-tenth of the change in inventory value are combined by the NIST Data Processor into one variable, the change in production cost. Client-reported inventory changes are modeled as changes in the annual cost of holding inventory, which is assumed to be $10 \%$ of the reported inventory change. These holding costs include charges for financing, insurance, and warehousing. 
The NIST Data Processor adjusts the change in production cost for inflation and then annualizes it. It then takes each year's annualized amount and adds the annualized amounts from the previous two years. This is done to let the original client-reported impact persist for two years. Impacts from 1993 and 1994 are assumed to be zero.

Figure 4 illustrates the two-year impact persistence model, using the hypothetical impact presented in Figure 3. Each inflation-adjusted, annualized amount from the overall reported impact (the 2-month, 12-month, and 4-month portions) is allowed to persist for two years.

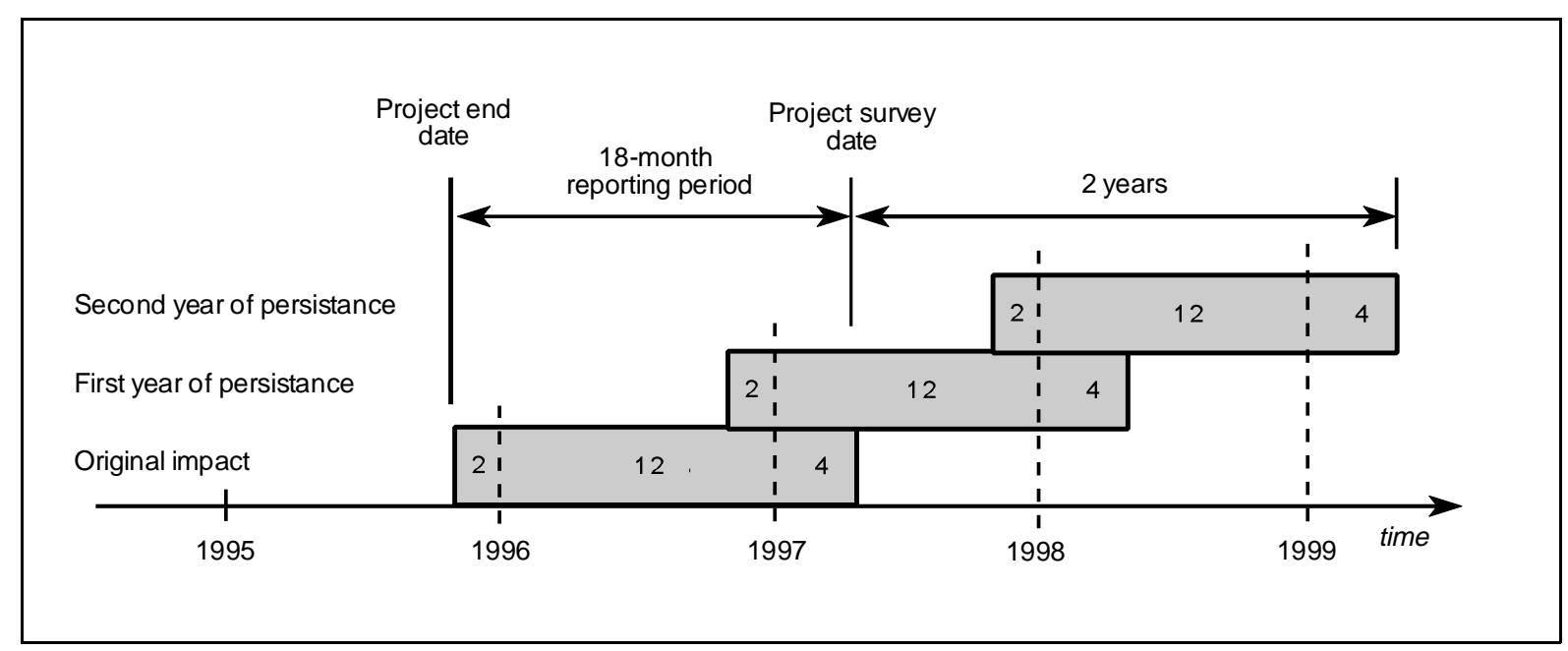

Figure 4. Persistence of a Client-Reported Impact

To avoid overlapping, the first year of persistence is drawn stacked on top of the initial impact. Likewise, the second year of persistence is shown another year forward on the time line, and is drawn above the first year of persistence.

Figure 5 shows the resulting impact in each year, after the impact is allowed to persist for two years. 


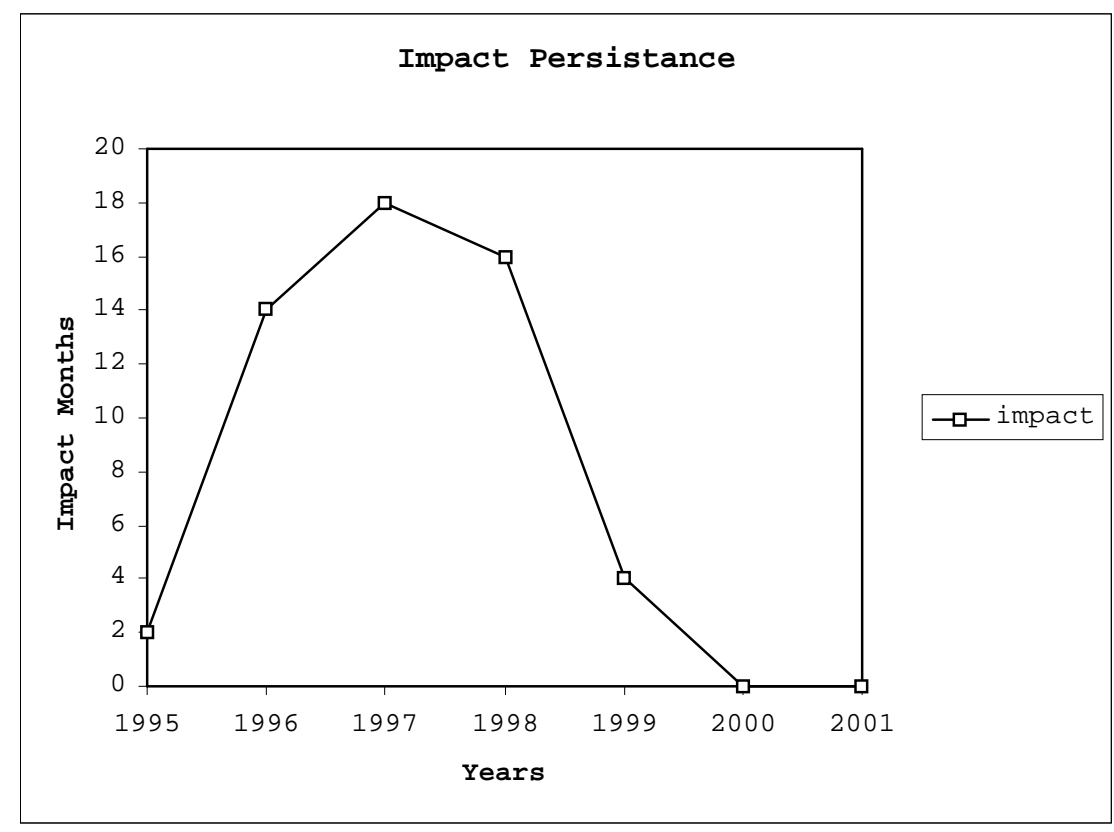

Figure 5. Impact Persistence Graph

Figure 5 shows the impact months—-proportional to the impact amount-for the years 1995 through 2001. In this case, the NIST Data Processor would generate production cost impacts of zero in the years 2000 and 2001. Therefore, all seven years (1995-2001) are accounted for.

Now, all impacts are summed by two-digit-SIC manufacturing industry. The NIST Data Processor outputs seven cost impacts (1995 to 2001) to the NIST REMI Input File, in 1992 base year dollars and by two-digit-SIC manufacturing industry.

\subsection{Adjust Sales Impacts}

All projects which have been classified as "sales projects" (Figure 2) have a positive or negative dollar amount by which sales increased or decreased. The NIST Data Processor has already adjusted the sales numbers for inflation, and has performed the annualizing adjustment.

Some fraction of the sales reported in the Census Follow-up Survey are new sales and represent an increase in total state output. But, the remaining fraction displace the sales of an in-state firm not surveyed in the Census Follow-up Survey, a problem sometimes referred to as "beggar thy neighbor" (see Glossary in Appendix A). The latter fraction of sales do not represent a net increase in total state output.

Therefore, the NIST Data Processor makes a special adjustment to sales. It estimates the amount of sales which represent an increase in total state output—sales which do not displace other in-state firms.

The NIST Data Processor uses location-of-sales data from the Census Follow-up Survey and divides the sales impact (after the inflation and annualizing adjustments) into sales made in-state and sales made out-of-state. Out-of-state sales include both sales made in other U.S. states and sales made in 
other countries (exports). If a firm did not report the location of sales, the NIST Data Processor assumes all sales occurred in-state. Sales made in-state are assumed to be satisfying local state demand, which itself is assumed to be fixed and unaffected by the MEP program. Local state demand is satisfied by either locally produced products sold in-state, or imports sold in-state. This breakdown is depicted in Figure 6.

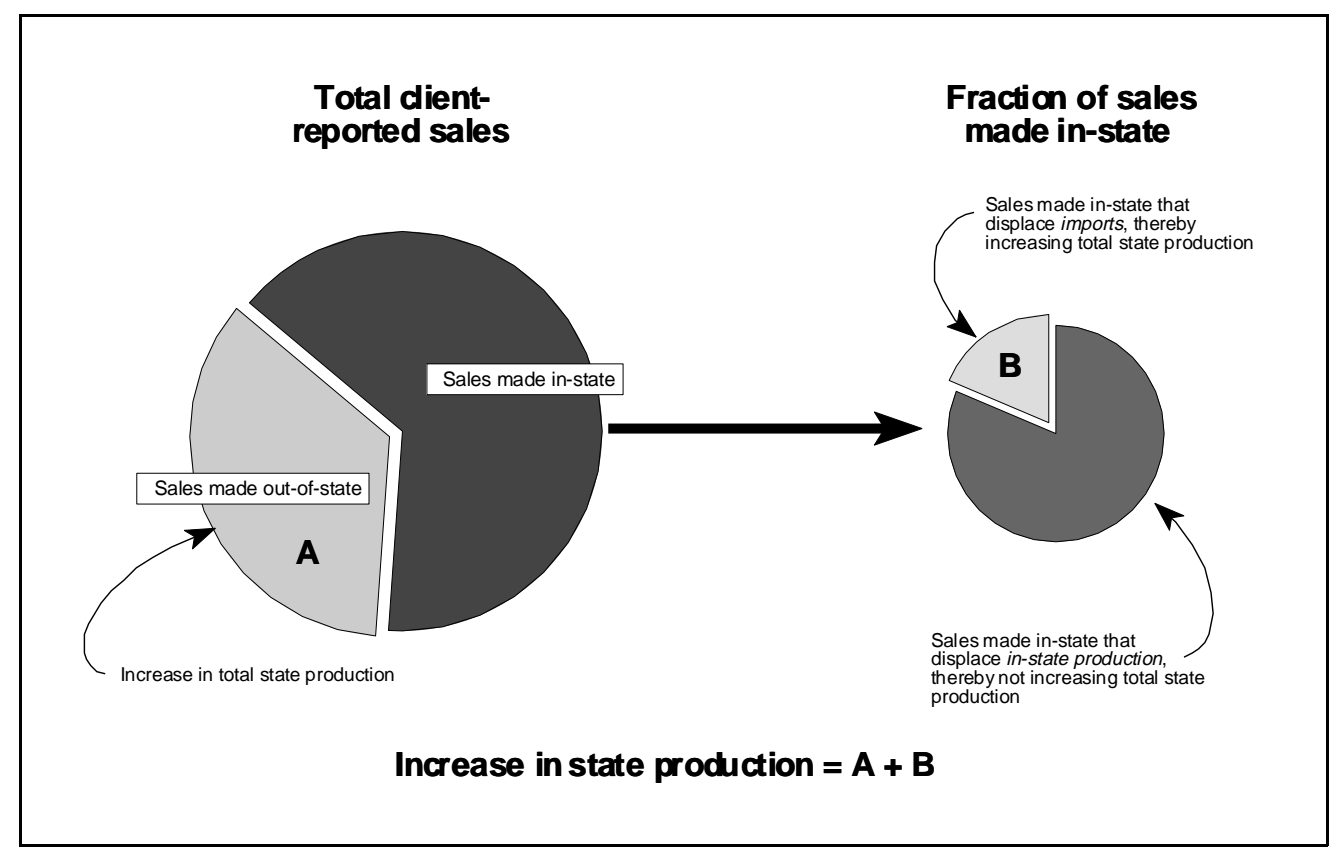

Figure 6. Location of Sales

All sales made out-of-state are not assumed to displace the existing sales of other in-state firms, and are thus counted in full (area A). The NIST Data Processor only counts in-state sales that displace imports (area B); sales made in-state that displaced local producers are not counted. The NIST Data Processor estimates this import displacement by multiplying sales made in-state by the fraction of imports sold instate over local state demand for the same SIC manufacturing industry, and for the same year, as the sales being adjusted. The data needed from the REMI baseline forecast are imports sold in-state and local state demand, by SIC manufacturing industry and year.

The net change in-state production is the sum of the sales made out of state (area A) and the countable sales made in-state (area B). As an example, equation (1) illustrates the adjustment made by the NIST Data Processor for sales made in 1995.

$$
\text { sales impact }_{1995}=\left(S_{95} \times \frac{100-\text { instate }}{100}\right)+\left(S_{95} \times \frac{\text { instate }_{100}}{\text { import }_{95}}\right)
$$

The variable $S_{95}$ represents the total sales impact for 1995 and is constructed from the annualizing adjustment of the Census Follow-up Survey. The variable instate is the percent of the sales impact made in-state and is obtained from the location-of-sales data in the Census Follow-up Survey. The imports and demand variables are obtained from the REMI baseline forecast. The NIST Data Processor 
generates sales impacts in the same way for the years 1996 to 2001. If the sales impact in a particular year is zero, the NIST Data Processor still reports that year, but with a zero impact. Therefore, all seven years (1995-2001) are accounted for.

The resulting sales impact for each year is then adjusted by the NIST Data Processor per Table 3. The NIST Data Processor adds the sales impacts from the previous two years to the current year's sales impact. This adjustment reflects the assumption that reported sales persist for an additional two years. Then all impacts are summed by two-digit SIC manufacturing industry. The NIST Data Processor outputs seven sales impacts (1995 to 2001) to the NIST REMI Input File, in base year dollars and by two-digit-SIC manufacturing industry.

\subsection{Adjust Jobs (Created and Retained) Impacts}

All projects which have been classified by the NIST Data Processor as "jobs projects" (Figure 2) have usable quantities for one or both of the following: the net number of jobs created or lost (positive or negative), and the number of jobs retained which would otherwise have been eliminated (positive).

Jobs created (or lost) and jobs retained are added together by the NIST Data Processor. The sum may be a negative number if the number of jobs lost is greater than the number of jobs retained. This produces the net number of jobs created or retained in each project. The NIST Data Processor does not net out increases and decreases in jobs at any level other than the individual project level. This is because firms that report jobs increases are assumed to be undergoing a fundamentally different change than firms that report decreases.

At this point, the NIST Data Processor has already performed the annualizing adjustment, and there is no need to adjust jobs for inflation. Further adjustments that the NIST Data Processor makes to jobs created or retained depend upon whether the net jobs amount is positive or negative.

\section{Net Increase in Jobs}

An increase in jobs created or retained is assumed to directly increase client-firm production above the level it would otherwise have been without assistance. The NIST Data Processor converts the increase in jobs to an increase in output by multiplying the increase in jobs by the ratio of local state output over local state employment for the same industry and year as the jobs being adjusted. The REMI baselineforecast data needed for this calculation are state employment and output, by two-digit SIC code and by year.

Some fraction of the resulting output change will displace the sales of other in-state firms. Therefore, as is done for sales, the output resulting from an increase in jobs is adjusted by the NIST Data Processor. As an example, equation (2) illustrates the adjustment made by the NIST Data Processor for jobs created or retained in 1995.

$$
\text { jobs impact }_{1995}^{+}=J_{95}^{+} \times \frac{\text { output }_{95}}{\text { employee }_{95}} \times \frac{\text { import }_{95}}{\text { demand }_{95}}
$$

In equation $2, J_{95}^{+}$represents the total jobs added in 1995 (obtained from the annualizing adjustment). 
The output, employee, imports, and demand data are obtained from the REMI baseline forecast. The resulting jobs impact for 1995 then continues to be adjusted by the NIST Data Processor per Table 3. The NIST Data Processor adds the jobs impacts from the previous two years to the current year, reflecting the assumption that reported jobs persist for an additional two years. Then all impacts are summed by two-digit-SIC manufacturing industry.

Now the NIST Data Processor makes a special adjustment to the jobs impact so that it may be input into the REMI model. A jobs impact is converted into a percent change in the two-digit-SIC industry's regional purchase coefficient (RPC), defined as the fraction of local state demand satisfied by goods produced in-state. When an increase in jobs causes more in-state production, the RPC increases, as shown in equation (3).

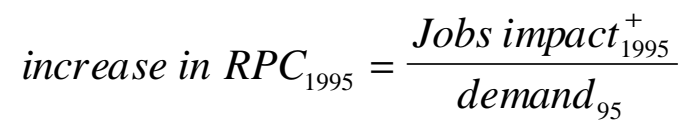

Equation (3) is performed for each year in the period 1995 to 2001, using the jobs impacts from equation (2) and demand numbers from the REMI baseline forecast. The NIST Data Processor outputs seven jobs impacts (1995 to 2001) to the NIST REMI Input File as percent productivity increases by two-digit-SIC manufacturing industry.

\section{Net Decrease in Jobs}

A decrease in jobs is modeled as a productivity increase-the firm produces the same output with fewer workers. The NIST Data Processor converts the decrease in jobs to a percent employment decrease, using the total industry employment in the state (obtained from REMI baseline-forecast data). The NIST Data Processor then translates the percent employment decrease into a percent productivity increase for input into REMI.

As an example, equations (4) and (5) illustrate the adjustment made by the NIST Data Processor for a net decrease in jobs created or retained in 1995.

$$
\begin{aligned}
& \text { percent employment decrease }=(-100) \times \frac{J_{95}^{-}}{\text {employment }_{95}} \\
& \text { productivity increase }_{1995}=\frac{100 \times \text { percent employment decrease } e_{1995}}{100-\text { percent employment decrease } e_{1995}}
\end{aligned}
$$

In equation $4, J_{95}^{-}$represents the decrease in jobs in 1995 (obtained from the annualizing adjustment). The employment data are obtained from the REMI baseline forecast. The percent employment decrease generated by equation (4) is then used in both the numerator and denominator of equation (5). The resulting productivity increase continues to be adjusted by the NIST Data Processor per Table 3 . The NIST Data Processor performs the two-year persistence adjustment, adding the jobs impacts from the previous two years to the current year. All impacts are summed by two-digit-SIC manufacturing industry. Then the NIST Data Processor outputs the jobs impacts to the NIST REMI Input File as 
percent productivity increases, by two-digit-SIC manufacturing industry and year.

\subsection{Adjust Investment Impacts}

All projects which have been classified as "investment projects" (Figure 2) have a positive dollar amount of new capital investment. The NIST Data Processor has already adjusted the capital investment numbers for inflation and performed the annualizing adjustment.

An increase in capital investment is assumed to increase output. The NIST Data Processor multiplies the adjusted capital investment by the yearly depreciation rate for capital in that industry. This yields a conservative estimate of the new capital used each year in production. The product is then multiplied by the output per capital used. The result is an estimate of the output associated with the capital investment impact. The NIST Data Processor assumes the output associated with this capital investment change is all sold in-state. Some fraction of the resulting output change will displace other in-state firms not in the Census Follow-up Survey Data. Therefore, as is done for sales, the output resulting from an increase in capital investment is adjusted by the NIST Data Processor. As an example, equation (6) illustrates the adjustment to capital investment in 1995.

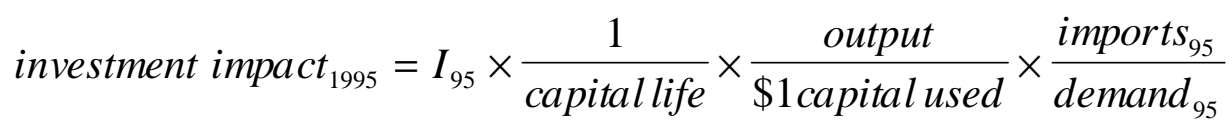

In equation (6), $I_{95}$ represents the capital investment in 1995 (after the inflation and annualizing adjustments). The imports and demand variables are obtained from REMI Baseline-Forecast data. The NIST Data Processor acquires industry capital life data from the Bureau of Labor Statistics[13] (see Appendix A) and industry "output per capital used" data from REMI (the company). Investment impacts for the years 1996 to 2001 are done in a similar manner.

Returning to the process outlined in Table 3, the NIST Data Processor adds the investment impacts from the previous two years to the current year's investment impact. This adjustment reflects the modeling assumption that reported investment persists for an additional two years.

The investment impact is input in REMI as an increase in the regional purchasing coefficient (RPC). The NIST Data Processor converts each year's investment impact into a percent increase in the industry RPC. As an example, equation (7) illustrates the adjustment made by the NIST Data Processor for the 1995 capital investment impact.

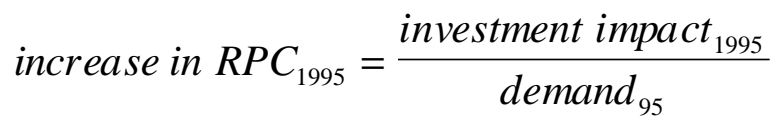

Equation (7) is performed for each year 1995 to 2001, using the investment impact calculated in equation (6) and the demand figures from the REMI baseline forecast for the appropriate year. If the investment impact in a particular year is zero, the NIST Data Processor still reports that year, but with a zero impact. Therefore, all seven years (1995-2001) are accounted for. 
All of the RPC increases are then summed by two-digit-SIC manufacturing industry. The NIST Data Processor outputs seven capital investment impacts (1995 to 2001) to the NIST REMI Input File, as percent increases in the RPC, by two-digit-SIC manufacturing industry and year.

\subsection{Conclusions}

When the NIST Data Processor finishes adjusting the data, it outputs two files. The first, the NIST Data Report, lists the summary statistics needed for the text and Table 1 of the two-page summary report (see Chapter 5). The second, the NIST REMI Input File, contains the industry impacts ready for input into REMI. If you own the REMI model, you will input the NIST REMI Input File yourself. If you are having REMI (the company) or another agency perform the simulations for you, NIST will send this file directly to the them. 


\section{Estimate State Macroeconomic Impacts}

Once the client-reported impacts have been converted to industry-level impacts using the NIST Data Processor, the next step is to estimate state macroeconomic impacts. This chapter provides guidelines for using the NIST REMI Input File and the REMI model to estimate the impact on the entire state economy. It first describes the REMI model itself, so that you understand the scope and purpose of the model. It then describes how to perform an impact simulation in REMI.

\subsection{The REMI Model ${ }^{1}$}

The REMI model was developed for regional economic planners and analysts who need to estimate the impacts of changes to their economy. In addition to several recent NIST studies[2,3,4], the model has been used extensively for economic development, forecasting and planning, transportation projects, environmental-policy analysis, energy and natural resource analysis, and taxation, budget, welfare, and federal economic policies. In general, the model computes the total effect over time on a regional economy, such as a state, of a change to a component of the economy. In the case of your center's impacts on the state economy, if your center has client-reported impacts over, say, the four-year 19972000 period, REMI can model the multi-year client-reported impact in those years and report the state impact as a time series over, say, the 1997-2005 period.

The model is based on economic theory, input-output (I/O) accounting, and econometrically estimated, time-dependent relationships between components of the economy. Figure 7 illustrates the structure of the variables and relationships in the REMI model.

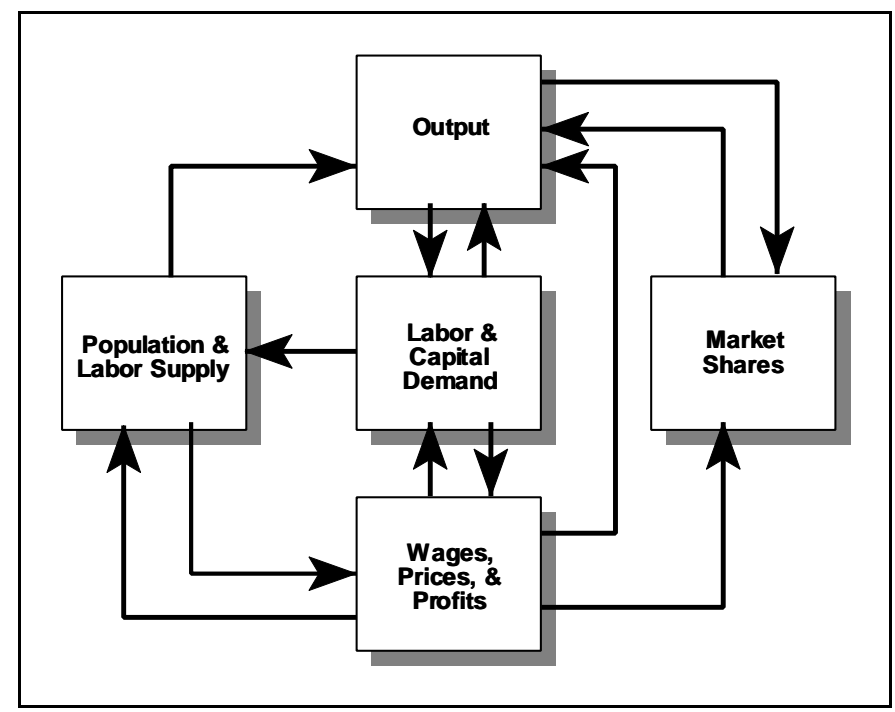

Figure 7. Economic Variables and Causal Relationships in the REMI Model

Each block in Figure 7 contains economic variables, each of which serve to model changes and

\footnotetext{
${ }^{1}$ For a comprehensive description of the REMI model see Treyz[11].
} 
measure changes in components of the economy. For example, the Output block contains measures of industry output, by two-digit SIC code and the type of demand (consumption, investment, government, and net exports), along with the input-output structure of industrial production. When modeling an increase in sales or output in, say, SIC 35, you can both adjust the level of SIC 35 output and see how it responds over time. Economic equations dictate the relationships between variables in different blocks; for example, the level of industry output determines the labor needs for that industry, as illustrated in Figure 7 by the arrow pointing from Output to Labor \& Capital Demand.

The model computes state impacts as the difference between a baseline forecast of the state economy and an alternative forecast that includes the modeled changes, i.e., the industry changes that result from the client-reported impacts. Since both forecasts are time series of economic data, the state macroeconomic impacts - the difference between the two forecasts-is also a time series, as illustrated in Figure 8. Viewing data on the changes to output, employment, and personal income allows one to characterize the fundamentally dynamic response of the entire state economy to changes in individual industries.

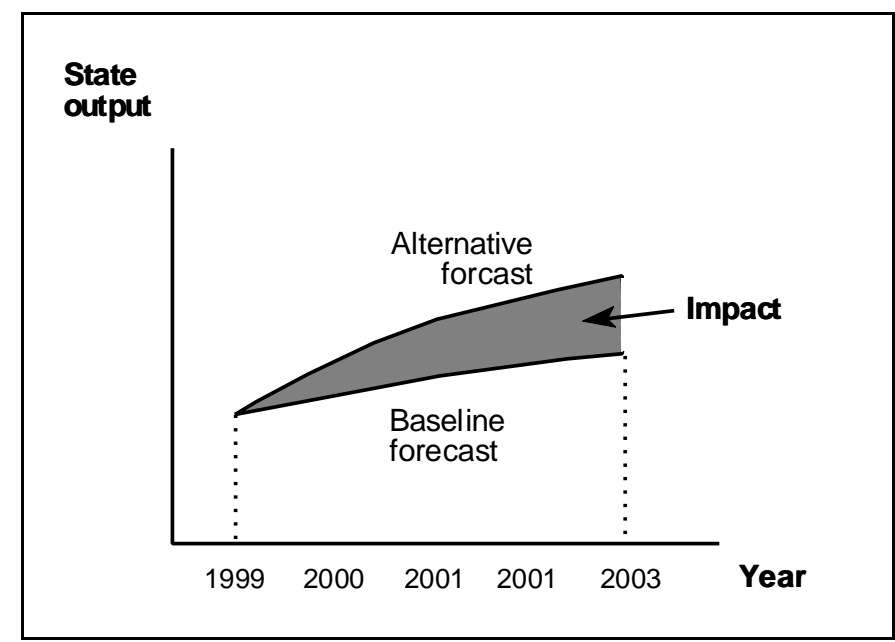

Figure 8. An Example of How to Measure Impacts in REMI

\subsection{Run a REMI Simulation of State Impacts}

Since the NIST Data Processor generates an impact file that REMI imports directly, the process of running a REMI simulation of state impacts is greatly simplified. The following sections explain this process.

There are five tab panels in the REMI software, representing five components of a REMI simulation:

- Forecast Selection - setting the baseline forecast parameters

- Policy Variable Selection - selecting the parts of the economy on which to model impacts.

- Policy Variable Values - setting the values of the impact-related adjustments

- Run Options - setting run parameters and running the simulation

- Results - viewing the results of the simulation 
Given that the NIST REMI Input File is used to import the impacts directly into the REMI model, you will not need to use the Policy Variable Selection panel, but rather can proceed directly to importing the Input file in the Policy Variable Value tab panel.

\section{Forecast Selection}

REMI presents macroeconomic impacts as the difference between the baseline forecast and the alternative forecast. Therefore, the first step is to select a baseline forecast of the state economy, i.e., a forecast where there are no changes caused by the client-reported impacts in the Census Follow-up Survey. This forecast is has already been run by REMI (the company). The Forecast Selection tab panel is shown below in Figure 9.

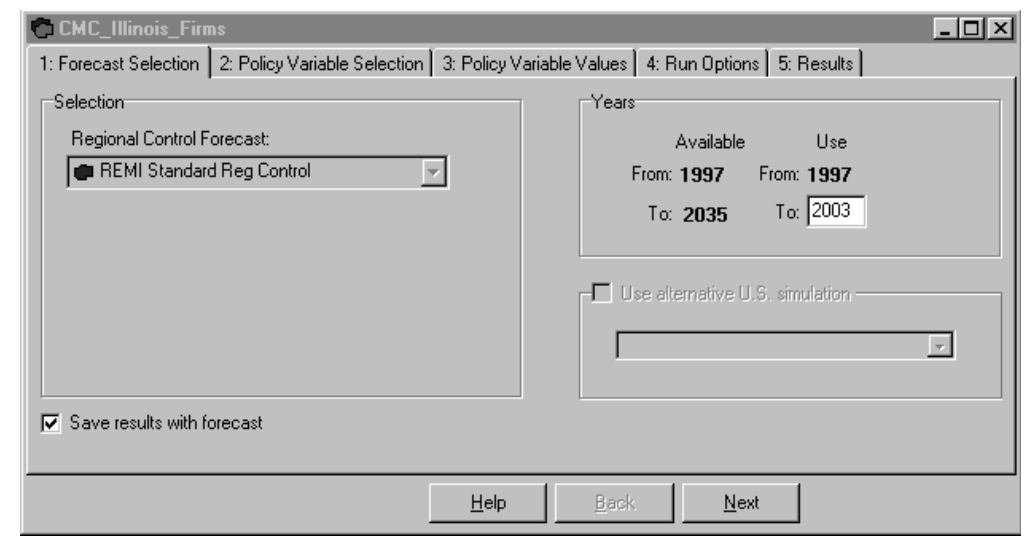

Figure 9. Forecast Selection tab

Forecast simulations can only be carried out in years that occur after the last year of REMI historical data. In the REMI Forecast Selection shown in Figure 9, the last year of historical data is 1996. Thus the earliest forecast year is 1997, and the forecast is being run from 1997 to 2003 inclusive. The NIST Data Processor shifts all impacts forward to the earliest forecast year. For example, impacts that occurred in 1995 are entered in REMI as 1997 impacts, and the macroeconomic impacts reported by REMI for the modeling years 1997 to 2003 are estimates of the effects in reporting years 1995-2001.

\section{Policy Variable Values}

The next step is to input the economic changes caused by the client-reported impacts; these data are contained in the NIST REMI Input File. To import the NIST REMI Input File, select the Policy Variable Values tab panel (skip the Policy Variable Selection tab panel). From the menu, choose File, then Import. Find the NIST REMI Input File on your computer (the file yrstate.txt in Figure 10) and then click on "Open." 


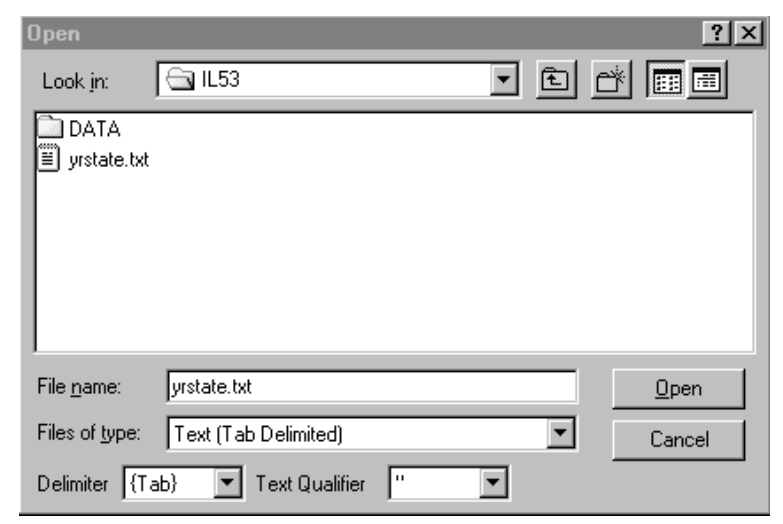

Figure 10. Importing the NIST REMI Input File

The adjusted impacts for your state are now in REMI; they can be viewed in the right-hand-side spreadsheet of input variables.

\section{Run Options}

The next step is to run the alternative forecast in the Run Options tab panel (Figure 11). If you own the REMI model, run the alternative forecast out to the year 2003 or later. If you are having REMI (the company) perform the simulations for you, this panel will be disabled.

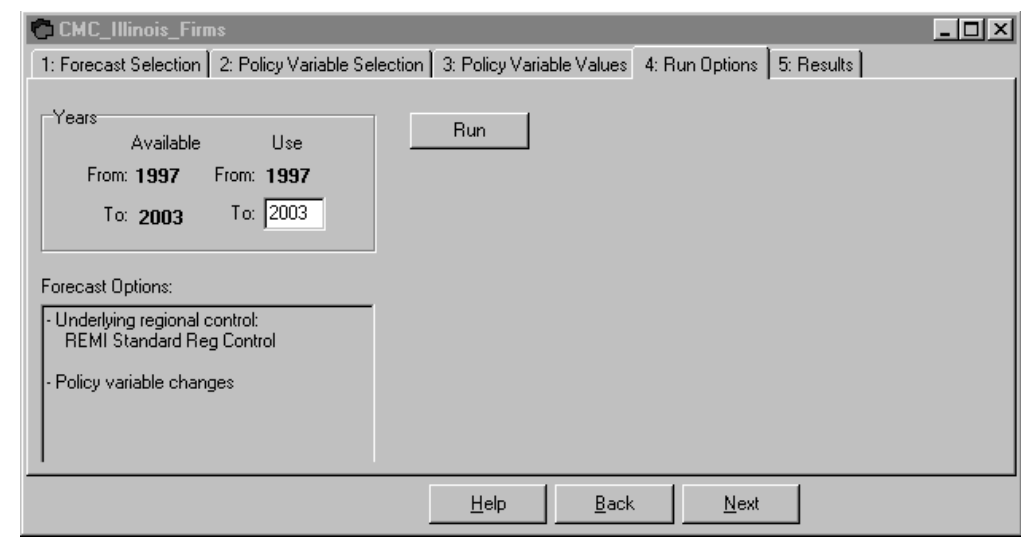

Figure 11. Run Options Tab Panel

\section{Results}

Figure 12 shows the Results tab panel. Because the NIST Data Processor shifted the years of the clientreported impacts forward two years so that they would occur during the REMI forecast period, the results must be shifted back two years (this is done automatically in the NIST Excel ${ }^{\mathrm{TM}}$ spreadsheet described below). For example, all the impacts that REMI calculated for 1997 should be thought of as occurring in 1995. 


\begin{tabular}{|c|c|c|c|c|c|c|}
\hline CMC_Illinois_Firms & & & & & -15 & 미 \\
\hline 1: Forecast Selection | 2: Policy Variab & le Selection | 3: Policy Variab & ble Values 4 : & 4: Run Options & 5: Results & & \\
\hline Type: Differences & are To: & Control & & & Years... & \\
\hline 日间 [Top] & Variable & 1997 & 1998 & 1999 & 2000 & $\Delta$ \\
\hline + 間 Analytical Organizatio & \begin{tabular}{|l} 
Employment (Thous) \\
\end{tabular} & +0.03125 & +0.1733 & +0.2026 & +0.2051 & \\
\hline 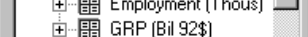 & GRP (Bil 92\$) & +0.001984 & +0.01144 & +0.01398 & +0.01471 & \\
\hline + 盟 Pers Inc (Bil Nom \$) & Pers Inc (Bil Nom \$) & +0.001282 & +0.007446 & +0.009583 & +0.01053 & \\
\hline+ 盟 PCE-Price Index $92 \$$ & PCE-Price Index 92\$ & $+8.392 \mathrm{E}-5$ & +0.0003967 & +0.0005341 & +0.0006332 & \\
\hline +盟 Real Disp Pers Inc (Bi & Real Disp Pers Inc (Bil 92\$) & +0.0007019 & +0.004242 & +0.00531 & +0.005615 & \\
\hline +盟 Population (Thous) & \begin{tabular}{|l|} 
Population (Thous) \\
\end{tabular} & +0.01172 & +0.05469 & +0.1016 & +0.1406 & \\
\hline $1+$ 間 Natality Rates (Female $=$ & $\begin{array}{lll}1 & 11 \\
\end{array}$ & 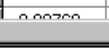 & a agar & & nman, & \\
\hline Master Standard,Custom & Table Graph & & & & & \\
\hline & Help & Back & 槽 & & & \\
\hline
\end{tabular}

Figure 12. Results Tab Panel

REMI measures impacts as the difference between the baseline forecast and the alternative forecast. Make sure that "Differences" is chosen in the Type box. A select set of these differences is used in the two-page summary report described in the next chapter. 


\section{Report Results}

\subsection{Determine the Best Format for Reporting Results}

Once your macroeconomic analysis is completed, you need to report the results. The impact measures you ultimately choose to report depend largely on the needs of your audience, be they center directors, marketing staff, or legislative liaisons. The REMI model supports your need for flexibility by offering data on hundreds of variables, including industry output, exports, imports, employment, wages, prices, production costs, and more. Still, your presentation should be concise. Therefore, this section describes a two-page summary report, shown in Figures 10 and 11, that will serve as an excellent template and starting point for your own report. Depending on your audience, you can optionally add other results and information to support your presentation.

Table 2 in this summary report (see Figure 11) presents four common macroeconomic-impact measures: one measure of economic growth (the change in state value-added output), two measures of employment (the change in employment and personal income), and, optionally, measures of fiscal impact (the changes in local, state, and federal tax revenues). These four give a concise picture of state macroeconomic impacts.

The two-page summary report is designed to

- Summarize the Census Follow-up Survey process. It identifies the centers for which macroeconomic impacts are being measured, describes the survey process, and lists the number of projects that were surveyed.

- Tabulate the client-reported impacts. It lists in table form the aggregate client-reported impacts, by type of impact (Table 1 in the report).

- Describe how state macroeconomic impacts are estimated. It describes the REMI model and some important modeling assumptions.

- Summarize the macroeconomic impacts. It lists the estimated macroeconomic impacts over a four-year forecast period, including the total impact (Table 2 in the report).

- Optionally compare the estimated change in-state tax revenues with center funding. If reporting the change in tax revenues, the report tabulates the tax revenue changes that result from the client-reported impacts (Table 2 in the report). 
Estimates of the Economic and Fiscal Impact of the Chicago Manufacturing Center (CMC) and Illinois Manufacturing Extension Center (IMEC) on the State of Illinois:

A Summary

September 9, 1998

The Office of Applied Economics at NIST recently completed a study of the state-level economic impacts of two Illinois manufacturing cxtension centers, the Chicago Manufacturing Center (CMC) and the Illinois Manufacluring Extension Center (IMEC). The sludy is based on a U.S. Department of Census survey of small manufacturers for which CMC and IMFC completed assistance hetween June, 1995 and May, 1997 (more recent results are being processed). The Census survey reports that CMC and IMEC helped its firms increase sales by $\$ 24.2$ million, create or retain 313 jobs, invest $\$ 16.0$ million in additional capital equipment, and save $\$ 5.8$ million in material, inventory, and labor costs.

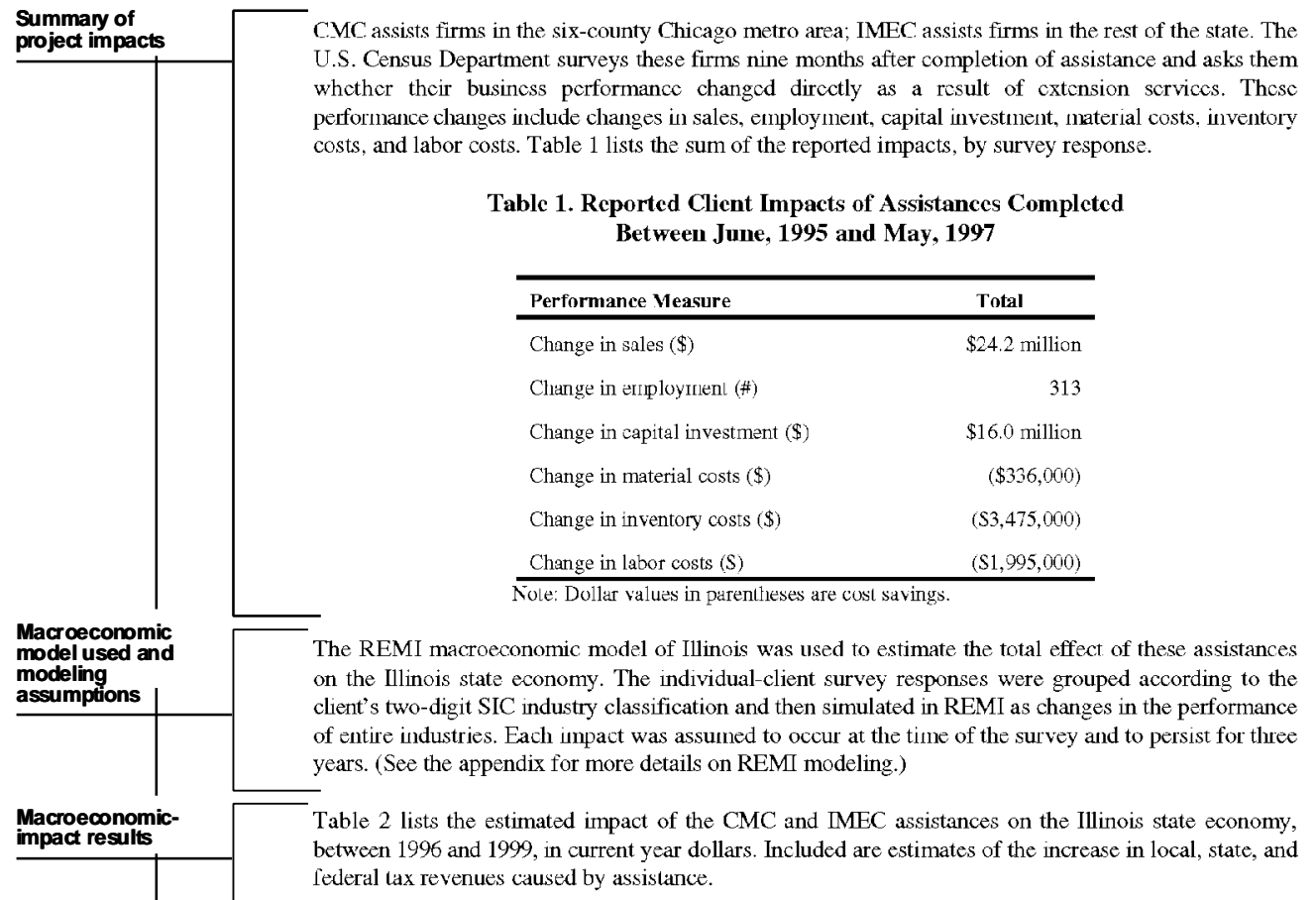

Figure 13. Page One of Two-Page Summary Report 


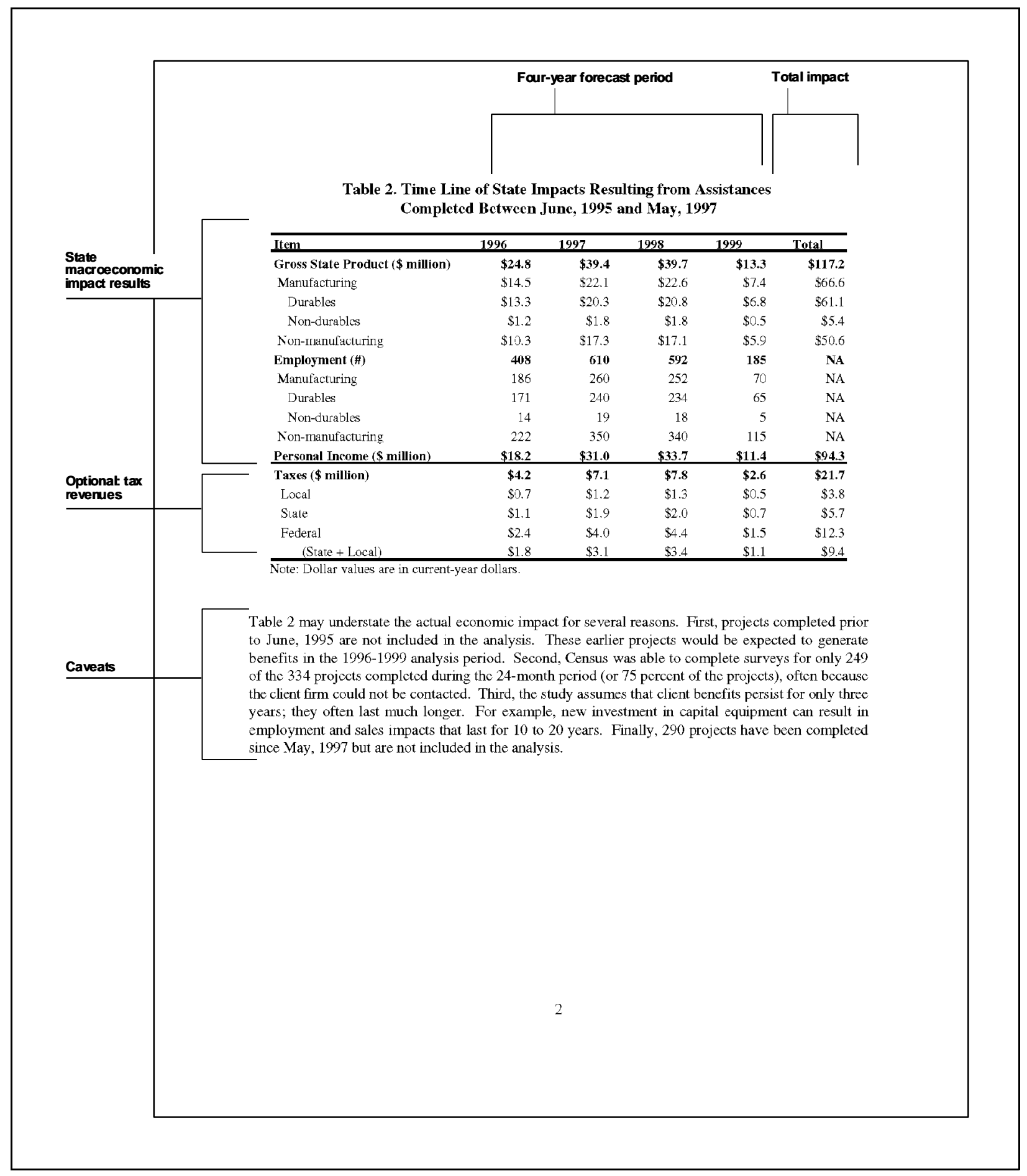

Figure 14. Page Two of the Two-Page Summary Report 


\section{Appendix: REMI Modeling Approach}

Each reported client impact was assumed to start ten months after completion of the associated project and persist over a three-year period. For example, if a firm reported that it created 10 jobs, these jobs were assumed to last 3 years. How each type of impact was handled in the model is described below.

Sales: Reported sales increases for each two-digit-SIC industry were adjusted according to where the sales were made. $\Lambda l l$ reported out-of-state and foreign sales were considered to be true increases in Ohio output. Reported sales to in-state customers, on the other hand. likely replace or crowd out some existing sales by Ohio firms to those in-state customers. Thus, the net increase in state output is best estimated to be the fraction of the reported sales that replace sales of non-Ohio firms to those customers. Since new in-state sales will. on average, crowd out non-Ohio firms' sales at a rate equal to the ratio of industry imports to industry demand, the net increase in state output for an industry, $O_{i}^{M}$, that results from reported in-state sales can be modeled as

$$
O_{i}^{M}=O_{i}^{R} \times\left(\frac{\text { imports }_{\mathrm{i}}}{\text { demand }_{\mathrm{i}}}\right),
$$

where $O_{i}^{R}$ is the reported in-state sales increase and $i$ denotes the two-digit-SIC manufacturing industry. Thus. total industry impact is the sum of out-of-state sales, plus foreign sales, plus $O_{i}{ }^{A}$.

Jobs and Capital Investment: Firms that reported job creation or retention only, increases in capital investment only, or both job creation/retention and increases in capital investment were assumed to be producing in-house that which would have otherwise been purchased elsewhere. As with sales, only afraction of these purchases do not displace other in-state firms' production. The net increase in state output for an industry, $O_{1}^{M A}$, that results from the reported jobs created or retained is calculated using the formula

$$
O_{i}^{M}=E_{i}^{R} \times\left(\frac{\text { output }_{\mathrm{i}}}{\text { employment }_{\mathrm{i}}}\right) \times\left(\frac{\text { imports }_{\mathrm{i}}}{\text { demand }_{\mathrm{i}}}\right),
$$

where $E_{i}^{k}$ is the reported number of jobs created or retained. Reported increases in capital or in both capital and labor were modeled in a similar fashion.

Combinations of job creation/retention and capital inyestment impacts that include sales impacts were modeled using the sales equation above. Any reported labor and capital increases were verified to be consistent with those sales impacts.

Material and Labor Savings: Reported material cost and labor cost changes were modeled as changes in industry production costs.

Inventory Reductions: Reported inventory cost changes were modeled as changas in the annual cost of holding inventory, which is assumed to be $10 \%$ of the reported inventory change. These holding costs include charges for financing, insurance, and warehousing

Figure 15. Appendix for the Two-Page Summary Report 


\subsection{Make the Two-Page Summary Report}

The data required for the report come from three sources: the NIST Data Report, the REMI alternative forecast, and the NIST Excel ${ }^{\mathrm{TM}}$ spreadsheet. The NIST Data Report, which you will receive from NIST, provides you with eight statistics for the text of the report:

- the total number of projects

- the number of projects with incomplete surveys

- the earliest and latest project end dates

- the earliest and latest project survey dates

- the average length of reporting period (the time from the project end to survey date)

- the number of projects with a reporting period longer than one year

- the number of projects in which the reporting period cannot be calculated

- the number of projects that reported an impact which cannot be quantified, and for which there is no substitute impact lower in the preference hierarchy

Beginning with the third set of statistics (earliest and latest project end dates), only completed projects are used to compute these data. The NIST Data Report also provides you the data for use in Table 1 of the report:

- sales changes, across all industries, all years

- jobs created or retained, across all industries and all years

- capital investment, across all industries and all years

- materials and labor cost (summed), across all industries and all years

- value of inventory reduction, across all industries and all years.

The NIST Data Report produces a snapshot of the client impacts in the Census Follow-up Survey Data File. Table 1 helps the reader of the two-page summary understand the project impacts that firms are reporting. (In contrast, the NIST REMI Input File contains data which has been adjusted for input into the REMI model; see Chapter 3.)

\section{Data in Table 2}

The simulation results and the NIST Excel ${ }^{\mathrm{TM}}$ spreadsheet together provide you with the state macroeconomic impact data needed for Table 2 of the summary report. If you had REMI (the company) perform the impact simulation or if you ran the simulation yourself, then you will need to locate and extract the impact data listed in the Results tab panel in the REMI model. If a third-party agency ran the simulation, then they will need to perform the extraction.

NIST has a standard method of extracting all the relevant information, copying it into an Excel ${ }^{\mathrm{TM}}$ spreadsheet created by NIST, and pasting information from Excel ${ }^{\mathrm{TM}}$ to the summary report. The mechanics of this process are simple and repeated for each type of results data needed: go to the appropriate category in the REMI Results tab panel, copy the line of data, and paste into the appropriate line in the NIST Excel ${ }^{\mathrm{TM}}$ spreadsheet, shown in Figures 16 and 17. 


\begin{tabular}{|c|c|c|c|c|c|c|c|c|}
\hline & $\mathrm{A}$ & $\mathrm{B}$ & $\mathrm{C}$ & $\mathrm{D}$ & $E$ & $\mathrm{~F}$ & G & $\mathrm{H}$ \\
\hline \multicolumn{9}{|l|}{1} \\
\hline 2 & Please enter: & & & & & & & \\
\hline \multicolumn{9}{|c|}{ 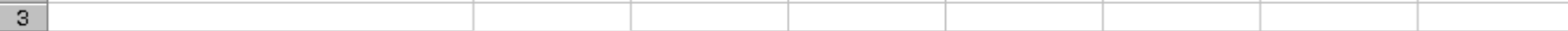 } \\
\hline 4 & Your State Tax \% & $0.00 \%$ & & & & & & \\
\hline 5 & Your Local Tax \% & $0.00 \%$ & & & & & & \\
\hline \multicolumn{9}{|c|}{ 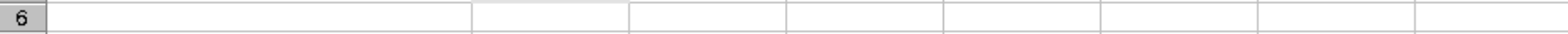 } \\
\hline 7 & & 1997 & 1998 & 1999 & 2000 & 2001 & 2002 & 2003 \\
\hline 8 & Paste from REMI: & & & & & & & \\
\hline \multicolumn{9}{|c|}{ 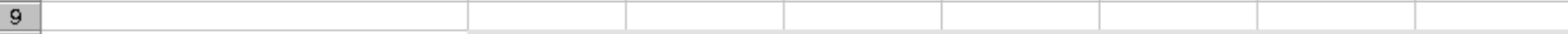 } \\
\hline 10 & Price Index (levels) & 0.0000 & 0.0000 & 0.0000 & 0.0000 & 0.0000 & 0.0000 & 0.0000 \\
\hline \multicolumn{9}{|l|}{11} \\
\hline 12 & Paste from REMI: & & & & & & & \\
\hline \multicolumn{9}{|l|}{13} \\
\hline 14 & Private Non-F arm GRP (Bi1 92\$) & 0.000000000 & 0.000000000 & 0.000000000 & 0.000000000 & 0.000000000 & 0.000000000 & 0.000000000 \\
\hline 15 & Durables Manuf. GRP (Bi192\$) & 0.000000000 & 0.000000000 & 0.000000000 & 0.000000000 & 0.000000000 & 0.000000000 & 0.000000000 \\
\hline 16 & Non-Durables Manuf. GRP (Bi192\$) & 0.000000000 & 0.000000000 & 0.000000000 & 0.000000000 & 0.000000000 & 0.000000000 & 0.000000000 \\
\hline \multicolumn{9}{|c|}{ 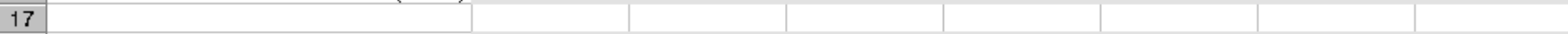 } \\
\hline 18 & Private Non-Farm Employment (Thous) & 0.000000000 & 0.000000000 & 0.000000000 & 0.000000000 & 0.000000000 & 0.000000000 & 0.000000000 \\
\hline 19 & Manufacturing Employment (Thous) & 0.000000000 & 0.000000000 & 0.000000000 & 0.000000000 & 0.000000000 & 0.000000000 & 0.000000000 \\
\hline 20 & Durables (Manuf.) Employment (Thous) & 0.000000000 & 0.000000000 & 0.000000000 & 0.000000000 & 0.000000000 & 0.000000000 & 0.000000000 \\
\hline 21 & Non-Durables (Manuf.) Employment (Thous) & 0.000000000 & 0.000000000 & 0.000000000 & 0.000000000 & 0.000000000 & 0.000000000 & 0.000000000 \\
\hline 22 & Non-Manufacturing Employment (Thous) & 0.000000000 & 0.000000000 & 0.000000000 & 0.000000000 & 0.000000000 & 0.000000000 & 0.000000000 \\
\hline \multicolumn{9}{|l|}{23} \\
\hline 24 & Personal Income (Bi1 Nom \$) & 0.000000000 & 0.000000000 & 0.000000000 & 0.000000000 & 0.000000000 & 0.000000000 & 0.000000000 \\
\hline
\end{tabular}

\section{Figure 16. Top Half of the NIST ExcelTM Spreadsheet}

Enter or paste values into all the named rows: taxes, price index, GRP, employment, and personal income. First enter information on your state and local tax rate, found in Appendix A. (Federal taxes are estimated to be $13 \%$ of personal income and have been already entered into the template.) Then, paste data from REMI into the remaining areas of the spreadsheet. Table 4 shows you where in REMI you will find the data. The spreadsheet only uses the price index for 2000 in its calculations, so you have a choice of pasting the whole price index line or just entering the 2000 price index. 


\begin{tabular}{|c|c|}
\hline Macroeconomic Impact & Location in REMI Results Menu \\
\hline Price Index & 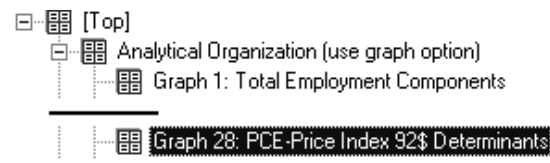 \\
\hline Gross State Product & 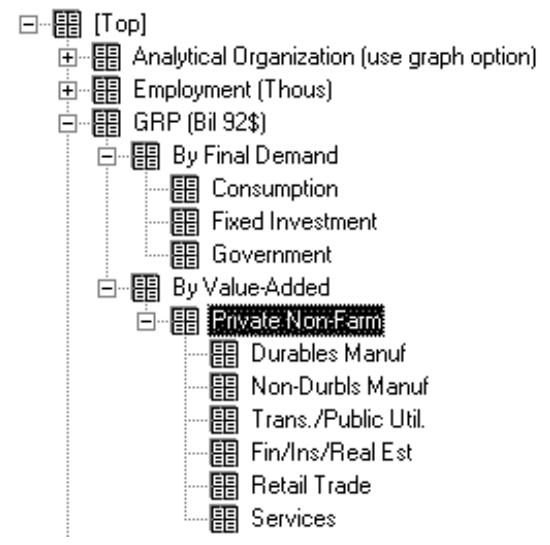 \\
\hline Total Employment & 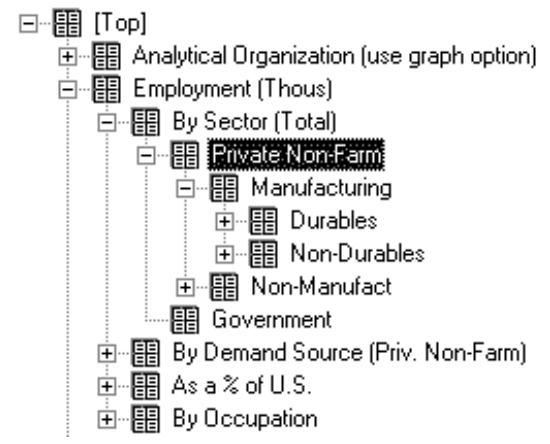 \\
\hline Personal Income & 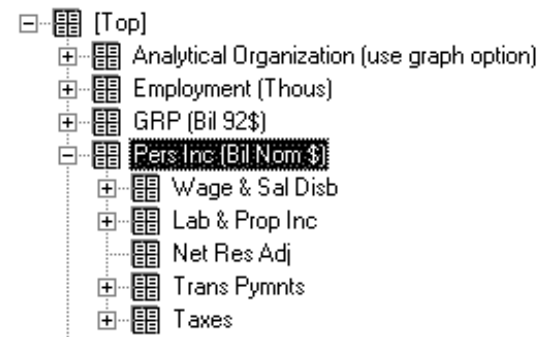 \\
\hline
\end{tabular}

Figure 17 shows the lower half of the NIST Excel ${ }^{\mathrm{TM}}$ spreadsheet before your data has been input (as indicated by the zeroes). Even though the table looks empty, the cells contain formulas. 


\begin{tabular}{|c|c|c|c|c|c|c|c|c|c|}
\hline 26 & & 1995 & 1996 & 1997 & 1998 & 1999 & 2000 & 2001 & Total \\
\hline \multicolumn{10}{|l|}{27} \\
\hline 28 & Gross State Product (million 99\$) & $\$ 0.0$ & $\$ 0.0$ & $\$ 0.0$ & $\$ 0.0$ & $\$ 0.0$ & $\$ 0.0$ & $\$ 0.0$ & $\$ 0.0$ \\
\hline 29 & Manufacturing & $\$ 0.0$ & $\$ 0.0$ & $\$ 0.0$ & $\$ 0.0$ & $\$ 0.0$ & $\$ 0.0$ & $\$ 0.0$ & $\$ 0.0$ \\
\hline 30 & Durables & $\$ 0.0$ & $\$ 0.0$ & $\$ 0.0$ & $\$ 0.0$ & $\$ 0.0$ & $\$ 0.0$ & $\$ 0.0$ & $\$ 0.0$ \\
\hline 31 & Non-Durables & $\$ 0.0$ & $\$ 0.0$ & $\$ 0.0$ & $\$ 0.0$ & $\$ 0.0$ & $\$ 0.0$ & $\$ 0.0$ & $\$ 0.0$ \\
\hline 32 & Non-Manufacturing & $\$ 0.0$ & $\$ 0.0$ & $\$ 0.0$ & $\$ 0.0$ & $\$ 0.0$ & $\$ 0.0$ & $\$ 0.0$ & $\$ 0.0$ \\
\hline 33 & Employment & 0 & 0 & 0 & 0 & 0 & 0 & 0 & $\mathrm{~N} / \mathrm{A}$ \\
\hline 34 & Manufacturing & 0 & 0 & 0 & 0 & 0 & 0 & 0 & $\mathrm{~N} / \mathrm{A}$ \\
\hline 35 & Durables & 0 & 0 & 0 & 0 & 0 & 0 & 0 & $\mathrm{~N} / \mathrm{A}$ \\
\hline 36 & Non-Durables & 0 & 0 & 0 & 0 & 0 & 0 & 0 & $\mathrm{~N} / \mathrm{A}$ \\
\hline 37 & Non-Manufacturing & 0 & 0 & 0 & 0 & 0 & 0 & 0 & $\mathrm{~N} / \mathrm{A}$ \\
\hline 38 & Personal Income (million 99\$) & $\$ 0.0$ & $\$ 0.0$ & $\$ 0.0$ & $\$ 0.0$ & $\$ 0.0$ & $\$ 0.0$ & $\$ 0.0$ & $\$ 0.0$ \\
\hline 39 & Total Taxes (million 99\$) & $\$ 0.0$ & $\$ 0.0$ & $\$ 0.0$ & $\$ 0.0$ & $\$ 0.0$ & $\$ 0.0$ & $\$ 0.0$ & $\$ 0.0$ \\
\hline 40 & Federal $(13 \%)$ & $\$ 0.0$ & $\$ 0.0$ & $\$ 0.0$ & $\$ 0.0$ & $\$ 0.0$ & $\$ 0.0$ & $\$ 0.0$ & $\$ 0.0$ \\
\hline 41 & State and Local & $\$ 0.0$ & $\$ 0.0$ & $\$ 0.0$ & $\$ 0.0$ & $\$ 0.0$ & $\$ 0.0$ & $\$ 0.0$ & $\$ 0.0$ \\
\hline 42 & State & $\$ 0.0$ & $\$ 0.0$ & $\$ 0.0$ & $\$ 0.0$ & $\$ 0.0$ & $\$ 0.0$ & $\$ 0.0$ & $\$ 0.0$ \\
\hline 43 & Local & $\$ 0.0$ & $\$ 0.0$ & $\$ 0.0$ & $\$ 0.0$ & $\$ 0.0$ & $\$ 0.0$ & $\$ 0.0$ & $\$ 0.0$ \\
\hline
\end{tabular}

Figure 17. Lower Half of NIST Excel ${ }^{\text {TM }}$ Spreadsheet

When you have completed pasting the data, the spreadsheet will calculate the data for the Table 2 of the summary report. Copy the data in Figure 17 to your report.

\subsection{Explain the Two-Page Summary Report}

Center personnel may need to verbally convey the results in the two-page summary or present the results in other publications. This section provides guidance on how to discuss the state impact results, including some caveats and supporting background information. Following the format in the Guide for Communicating Impact[10], this discussion material is presented according to:

- what you will be able to say;

- how the economic impact is calculated;

- how to explain the impact; and

- what to watch out for. 


\begin{tabular}{|c|c|}
\hline \multicolumn{2}{|l|}{ Gross State Product } \\
\hline $\begin{array}{l}\text { What you will be } \\
\text { able to say: }\end{array}$ & $\begin{array}{l}\text { "As a direct result of center services, gross state product increased by an estimated } \\
\$ 117.2 \text { million over the } 1996-1999 \text { period." }\end{array}$ \\
\hline How it is calculated: & $\begin{array}{l}\text { Gross state product, also known as state value-added output, is the difference between the } \\
\text { sales value of all in-state firms' output minus the cost of the inputs these firms purchased } \\
\text { from other firms. The REMI model estimates how in-state firms' output and costs are } \\
\text { affected by center projects. The change in the difference between these two variables is the } \\
\text { change in gross state product. }\end{array}$ \\
\hline & $\begin{array}{l}\text { Here's an example of how REMI models the state impact of center projects, in particular a } \\
\text { change in sales. New client sales generate new production in the client firm's industry and } \\
\text { in industries that supply inputs to it. This new production creates new jobs and income, the } \\
\text { latter of which is then spent on goods and services, creating more sales and production. } \\
\text { The change in gross state product is the new level of in-state firm output minus the new } \\
\text { level of costs of inputs from other firms. }\end{array}$ \\
\hline How to explain it: & $\begin{array}{l}\text { Explain that gross state product, or value-added output, is the best measure of the real } \\
\text { value produced in the state by labor and capital, since it nets out the value of the materials } \\
\text { embodied in product. Contrast value-added output with output measured by sales, that is, } \\
\text { the dollar value of the goods when they are sold. Here's an example: consider an in-state } \\
\text { firm that imports } 1000 \text { televisions at a cost of } \$ 100 \text { per television and } 1000 \text { stereos at a cost } \\
\text { of } \$ 100 \text { per stereo, packages one of each together, and then exports } 1000 \text { sets of } \\
\text { "multimedia centers" at a price of } \$ 220 \text { each. What is the change in value-added output in } \\
\text { the state? It is the value added in-state, that is, }(\$ 220 \text { - } \$ 100-\$ 100)=\$ 20 \text { per multimedia } \\
\text { center, or } \$ 20,000 \text {. Output as measured by sales, on the other hand, increases by } \$ 220 \mathrm{x} \\
1000=\$ 220,000 \text {. }\end{array}$ \\
\hline & $\begin{array}{l}\text { Explain that this value-added output approximately equals what is paid to workers and to } \\
\text { owners of capital, an example of the latter being owners of in-state firms. Gross state } \\
\text { product is retained within the state in the form of wages, salaries, and firm profits (which } \\
\text { are ultimately income). In the above example, the payments to labor and capital, both } \\
\text { factors of production, is } \$ 20,000 \text {. }\end{array}$ \\
\hline $\begin{array}{l}\text { What to watch out } \\
\text { for: }\end{array}$ & $\begin{array}{l}\text { Value-added output is often mistaken for output as measured by sales. Make clear to your } \\
\text { audience that gross state product is much lower in value than sales-based output but is a } \\
\text { better measure of what was both produced within the state and returned to its residents as } \\
\text { income. }\end{array}$ \\
\hline
\end{tabular}




\begin{tabular}{|c|c|}
\hline \multicolumn{2}{|l|}{ State Employment } \\
\hline $\begin{array}{l}\text { What you will be } \\
\text { able to say: }\end{array}$ & $\begin{array}{l}\text { "As a direct result of center services, state employment increased by an average of } 250 \\
\text { workers over a four-year period." }\end{array}$ \\
\hline & or \\
\hline & $\begin{array}{l}\text { "The } \$ 117 \text { million in new value-added production created an average of } 250 \text { new jobs } \\
\text { over the four-year period." }\end{array}$ \\
\hline How it is calculated: & $\begin{array}{l}\text { When the level and distribution of state production changes, either due to new levels of } \\
\text { production or due to shifts in production between sectors, REMI estimates the level and } \\
\text { distribution of labor needed to produce this output. For example, if output in SIC } 35 \\
\text { increases by one percent, then employment in SIC } 35 \text { will increase by a similar amount. } \\
\text { Similarly, percent shifts in output between sectors will cause similar percent shifts in } \\
\text { employment. The distribution of employment can also be affected by changes in sectoral } \\
\text { wages - workers may move to a higher paying job, but the strongest factor affecting } \\
\text { employment in a sector is the level of production in the sector. }\end{array}$ \\
\hline How to explain it: & $\begin{array}{l}\text { Explain that jobs are created whenever industry production increases, whether it be an } \\
\text { expansion of output or a switching of production from one sector to another. }\end{array}$ \\
\hline $\begin{array}{l}\text { What to watch out } \\
\text { for: }\end{array}$ & $\begin{array}{l}\text { The employment figures listed in 1996-1999 columns in Table } 2 \text { of the report cannot be } \\
\text { added up, since they are not new jobs created each year, but rather are simply the difference } \\
\text { between the REMI baseline and alternative forecasts. }\end{array}$ \\
\hline & $\begin{array}{l}\text { Not all of the new jobs are filled by in-state workers; some are filled by economic migrants, } \\
\text { or workers who commute daily from out-of-state. This means that while it is true that " } 250 \\
\text { jobs were created," it is not always true that " } 250 \text { state residents got new jobs." Of the in- } \\
\text { state workers who fill the new jobs, some are permanent immigrants who move to the state } \\
\text { for the job, thereby increasing state population. }\end{array}$ \\
\hline
\end{tabular}




\begin{tabular}{|ll|}
\hline Personal Income & \\
\hline $\begin{array}{l}\text { What you will be } \\
\text { able to say: }\end{array}$ & $\begin{array}{l}\text { "As a direct result of center services, state personal income increased by an estimated } \\
\mathbf{\$ 9 4} \text { million." }\end{array}$ \\
\hline How it is calculated: & $\begin{array}{l}\text { When output increases, new jobs are created and these new jobs generate new personal } \\
\text { income. At the same time, shifts of production from one industry to another cause the } \\
\text { distribution of employment to change, changing aggregate personal income. To compute the } \\
\text { change in personal income, REMI first computes the change in output, computes then } \\
\text { change in employment that results from the output change, and then computes the change in } \\
\text { personal income that results from the employment change. }\end{array}$ \\
\hline How to explain it: & $\begin{array}{l}\text { Personal income will likely increase for at least two reasons. First, the expansion of state } \\
\text { output will expand the employment base-more production requires more workers. } \\
\text { Second, personal income will rise if workers move to higher paying jobs. Emphasize that } \\
\text { even if aggregate employment does not change, the number of workers who switch to } \\
\text { higher-wage jobs can still be significant. }\end{array}$ \\
\hline $\begin{array}{l}\text { What to watch out } \\
\text { for: }\end{array}$ & $\begin{array}{l}\text { Be sure to not confuse personal income with returns to factors; they are slightly different } \\
\text { terms. Personal income is the sum of specific national income accounting concepts, } \\
\text { including wages, proceeds from the sale of assets, and transfer payments, but does not } \\
\text { include social security payments. Returns to factors, on the other hand, is the sum of } \\
\text { payments made to the factors of production, labor and capital. Payments to factors of } \\
\text { production at the state level are, by definition, equal to state value added output. }\end{array}$ \\
\hline
\end{tabular}

\begin{tabular}{|ll|}
\hline Optional: State and Local (and Federal) Tax Revenues \\
\hline $\begin{array}{l}\text { What you will be } \\
\text { able to say: }\end{array}$ & $\begin{array}{l}\text { "As a direct result of center services, state and local tax revenues increased by an } \\
\text { estimated \$9.4 million." }\end{array}$ \\
\hline How it is calculated: & $\begin{array}{l}\text { REMI does not directly compute local, state, and federal tax revenues; these must be } \\
\text { computed after simulation. The tax revenues shown in Table } 2 \text { of Figure } 11 \text { are computed } \\
\text { as a fraction of the estimated personal income increases, using values reported by the } \\
\text { Federation of Tax Administrators[5,6] and listed in Appendix A. }\end{array}$ \\
& $\begin{array}{l}\text { These taxes can also be computed as a fraction of gross state product, as is done in the } A \\
\text { Guide for Communicating Impact [10]. Both methods, along with other methods your own } \\
\text { state may estimate revenues, should produce similar tax revenue estimates. }\end{array}$ \\
\hline How to explain it: & $\begin{array}{l}\text { Explain that the client-reported impacts increase sales, income, and other concepts against } \\
\text { which your federal, state, and local governments levy taxes. }\end{array}$ \\
\hline $\begin{array}{l}\text { What to watch out } \\
\text { for: }\end{array}$ & $\begin{array}{l}\text { Before reporting changes in state tax revenues, decide whether reporting these tax revenues } \\
\text { will raise false expectations of fiscal neutrality that may not be realized every year. If you } \\
\text { define your metric for evaluating center performance as fiscal neutrality, then you will have } \\
\text { to explain benefit if you don't achieve this neutrality. Mention that there are other center } \\
\text { benefits to the state besides tax revenues, such as the observed (surveyed) increases in state } \\
\text { output, employment, and income, and the unobserved increases in firm productivity and } \\
\text { competitiveness. }\end{array}$ \\
\hline
\end{tabular}




\subsection{Further Explain the Results}

The two-page summary report is designed to be concise but sufficient. Sometimes you may, however, have a need-or opportunity - to present more economic data, whether to support your macroeconomic analysis or to further describe the client impacts. Results from the Census Follow-up Survey and the REMI alternative forecast provide numerous additional data which can increase the clarity and effectiveness of your presentation.

\section{Additional Uses of the REMI Simulation}

There are several natural extensions to the macroeconomic impacts reported in Table 2 of the report. Each of the following can be retrieved from the fifth, "Results" tab panel in REMI (Figure 12).

- Impact on gross state product, by two-digit-SIC manufacturing industry. This is a further breakdown of the change in durables and non-durables manufacturing gross state product listed in Table 2 of the summary report. These data are retrieved from the Results tab panel in REMI. When presenting these impacts, mention that this is the sum of direct and indirect impacts of the client-reported impacts, and that it is not the same as output as measured by sales; it is the value added in each industry.

- Impact on state employment, by two-digit SIC industry. This is a further breakdown of the change in employment shown in Table 2 of the report. The data are retrieved from the REMI "Results" panel. When presenting, mention that many of the employment increases have occurred in high-wage manufacturing sectors.

In addition to the simulation results, use the following factual information about REMI to support your analysis and results:

- The REMI model is used by over $40 \%$ of the state governments in the U.S. for analysis of their tax, energy, and economic development policies.

- REMI is one of the most highly regarded macroeconomic models. The model and analyses based on it have been critiqued in numerous refereed journal articles.

- The model is open-source, that is, the internal programming code is publicly documented.

- The model was developed by Dr. George I. Treyz, President of Regional Economic Modeling, Incorporated and former Professor of Economics at the University of Massachusetts at Amherst.

- A REMI model can be made of any set of county-level regions of the United States, such as a four-county statistical metropolitan area (SMA) or of a multi-state region of the United States.

\section{Additional Uses of The Census Follow-Up Survey}

The MEP publication A Guide for Communicating Impact[10] suggests numerous ways to report the 
direct impacts of the Census Survey data. Some of the data generated by the NIST Data Processor are good supporters of the client impacts reported in Table 1 of the summary report.

- Sales impacts by manufacturing industry. If your clients have reported large sales increases and these sales have occurred in manufacturing sectors important to the state economy, you can add a table or graph displaying the client-reported impacts by two-digit-SIC manufacturing industry. Use the data from the NIST Data Processor that lists sales impacts by two-digit SIC code and by destination of sales.

- Jobs impacts by manufacturing industry. Similarly, an additional table or graph can be added listing the client-reported jobs impacts (both created and retained) by industry. Use the table from the NIST automated process that lists employment impacts by two-digit SIC code.

The following information about or contained in the Census Survey data can be used to support your general presentation.

- The Census Follow-up Survey is an independent survey of MEP clients, in which these clients attest how MEP affected their business performance as a direct result of center services.

- On average, only $70 \%$ of a center's clients complete the survey. The impacts reported by clients, however, are not extrapolated to the clients not surveyed.

- The Census Survey captures at best only a fraction of the true impacts of the center services. Many other economic benefits, such as disseminating information about new technologies or increasing compliance of centers to industry codes, will not show up in the Survey results but do have potentially large impacts. 


\section{Appendix A: Supporting Information}

\author{
Table A1. Glossary \\ Term \\ Explanation
}

alternative forecast

baseline forecast

beggar thy neighbor

constant dollars

double counting of impacts

dynamic macroeconomic models
The REMI forecast of the state economy in which there are simulated, impactrelated changes to the economy. Economic impacts are measured by REMI as the difference between the baseline forecast and alternative forecast. See baseline forecast.

The REMI forecast of the state economy in which there are no simulated, impact-related changes to the economy. Economic impacts are measured by REMI as the difference between the baseline forecast and altemative forecast. See also alternative forecast.

To beggar thy neighbor is to, in the course of improving one's own condition, make a "neighbor" worse off. Relevant to state impacts, the sales increases that MEP clients report may only be displacing the existing sales of other instate firms; they "beggar" their neighbor. If so, there is no net increase in sales in the state. A client-reported sales impact does not beggar thy neighbor if it displaces imports from out-of-state forms, or if the sale is made to an out-ofstate customer who does not currently buy from an in-state firm. The NIST Data Processor takes full account of the beggar-thy-neighbor problem in reported sales by only including displaced imports (new sales that displace the in-state sales of out-of-state firms) and exports (new out-of-state sales).

An amount valued at the prices in a particular base or reference year, say, 1999. Consider an example: a client firm reports sales impacts in 1995 and 1999. These values should not be combined or compared since prices have changed from 1995 to 1999 . To correct for these price changes, the two amounts are converted to a reference year using a price index such as the Consumer Price Index (CPI) or the GDP Deflator. The NIST Data Processor converts dollar-valued client impacts to 1992 constant-dollar amounts before modeling in REMI. REMI then reports the macroeconomic impacts in constant 1992 dollars, which are then converted to constant dollars in a more recent year, say 1999, using the CPI. Compare with nominal dollars.

The act of counting the effect of a single MEP project twice. When modeling a project with sales and employment impacts in REMI, either the sales impact or the employment impact should be modeled but not both, since a sales impact generally implies that employment will increase, and vice-versa. To model both simultaneously would be double counting of impacts.

Economic models that analyze an economy over time, using time series data and intertemporal relationships between components of the economy. Unlike input-output models and multipliers, dynamic models allow for excess labor, excess capital, or excess supply or demand in any given market. REMI is a dynamic macroeconomic model. See Section 1.1 for more discussion. 


\begin{tabular}{|c|c|}
\hline \multicolumn{2}{|l|}{ Table A1. Glossary } \\
\hline Term & Explanation \\
\hline economic growth & $\begin{array}{l}\text { The increased productive capabilities of an economy. Economic growth can } \\
\text { be achieved from an increase in the resources available for production-land, } \\
\text { labor, and capital, and productive efficiency-or an increase in the efficient } \\
\text { use of these resources. MEP assistance helps achieve economic growth, for } \\
\text { example, by increasing sales which command additional labor and other } \\
\text { resources, and by improving the labor productivity and total factor } \\
\text { productivity of in-state firms. }\end{array}$ \\
\hline factors of production & $\begin{array}{l}\text { Re-usable resources used in production, generally labor and capital. To make } \\
\text { a manufactured product, a firm purchases products from other firms and } \\
\text { utilizes its factors of production. The value added to the economy is the value } \\
\text { created by the factors of production. }\end{array}$ \\
\hline fiscal neutrality & $\begin{array}{l}\text { When the tax revenues generated by a state program (e.g., the in-state MEP } \\
\text { centers) equal program funding. }\end{array}$ \\
\hline gross state product & See value-added output. \\
\hline input-output (I/O) models & $\begin{array}{l}\text { Economic models that model an economy as set of linear production functions } \\
\text { describing the interrelationships between sectors. I/O models are general } \\
\text { static representations of an economy, where markets are always cleared. See } \\
\text { Section } 1.1 \text { for more discussion. }\end{array}$ \\
\hline market failure & $\begin{array}{l}\text { Occurs when a market-based system does not provide certain goods at optimal } \\
\text { levels, or at all. The inability of small manufacturers to access the latest in } \\
\text { public information on process improvement, marketing, and information } \\
\text { technology is a market failure that MEP strives to prevent. }\end{array}$ \\
\hline multiplier & $\begin{array}{l}\text { The ratio of a change in output or income to a change in an expenditure that } \\
\text { brought it about. For example, the state output multiplier is the ratio of the } \\
\text { change in state output to a change in output in a component of the state } \\
\text { economy. If SIC } 35 \text { output were increased by } \$ 1 \text { million (say, through project } \\
\text { assistance) and this increase-through the additional intermediate goods } \\
\text { product, additional income, and additional spending-caused total state output } \\
\text { to increase by } \$ 2.5 \text { million, then the SIC } 35 \text { output multiplier is } 2.5 \text {. See } \\
\text { Section } 1.1 \text { for more discussion. }\end{array}$ \\
\hline nominal dollars & $\begin{array}{l}\text { An amount valued at the prices in the current year. A sales impact of } \$ 1 \\
\text { million that occurred in } 1999 \text { is valued at } \$ 1 \text { million in } 1999 \text { nominal dollars, } \\
\text { but would have a different value in other years, owing to inflation (a change in } \\
\text { prices). Client firms express dollar impacts in nominal dollars. Compare with } \\
\text { constant dollars. }\end{array}$ \\
\hline personal income & $\begin{array}{l}\text { The amount of income that individuals actually receive. The values of personal } \\
\text { income reported by REMI are based the standard definition: personal income } \\
=\text { national income - (undistributed corporate profits) - (social insurance taxes) } \\
\text { - (corporate profits taxes) + transfer payments. }\end{array}$ \\
\hline
\end{tabular}


Table A1. Glossary

Term

regional purchase coefficient

value-added output

\section{Explanation}

A number representing the fraction of state demand for a good or service that is produced by in-state firms.

A measure of the value created by the factors of production (labor and capital) It is measured as the sales value of output minus the cost of materials purchased from other firms. 
Table A2. Federal, State, and Local Tax Revenues as a Percent of Personal Income

\begin{tabular}{|c|c|c|c|c|c|}
\hline State & Total & Federal & $\begin{array}{l}\text { State } \\
\text { and } \\
\text { Local }\end{array}$ & State & Local \\
\hline All States & 24.3 & 13 & 11.3 & 7.0 & 4.3 \\
\hline ALABAMA & 22.4 & 13 & 9.4 & 6.4 & 3 \\
\hline ALASKA & 28.9 & 13 & 15.9 & 7.8 & 8.1 \\
\hline ARIZONA & 24.8 & 13 & 11.8 & 6.9 & 4.9 \\
\hline ARKANSAS & 23.8 & 13 & 10.8 & 8.2 & 2.6 \\
\hline CALIFORNIA & 24.3 & 13 & 11.3 & 8.0 & 3.3 \\
\hline COLORADO & 23.3 & 13 & 10.3 & 5.6 & 4.7 \\
\hline CONNECTICUT & 25.1 & 13 & 12.1 & 8.0 & 4.1 \\
\hline DELAWARE & 23.9 & 13 & 10.9 & 9.5 & 1.4 \\
\hline FLORIDA & 23.3 & 13 & 10.3 & 6.2 & 4.1 \\
\hline GEORGIA & 24.1 & 13 & 11.1 & 6.5 & 4.6 \\
\hline HAWAII & 26.2 & 13 & 13.2 & 10.4 & 2.8 \\
\hline IDAHO & 24.6 & 13 & 11.6 & 8.3 & 3.3 \\
\hline ILLINOIS & 23.9 & 13 & 10.9 & 6.0 & 4.9 \\
\hline INDIANA & 23.4 & 13 & 10.4 & 7.2 & 3.2 \\
\hline IOWA & 24.7 & 13 & 11.7 & 7.3 & 4.4 \\
\hline KANSAS & 24.4 & 13 & 11.4 & 7.5 & 3.9 \\
\hline KENTUCKY & 24.6 & 13 & 11.6 & 8.8 & 2.8 \\
\hline LOUISIANA & 23.3 & 13 & 10.3 & 6.8 & 3.5 \\
\hline MAINE & 25.9 & 13 & 12.9 & 8.7 & 4.2 \\
\hline MARYLAND & 23.6 & 13 & 10.6 & 6.3 & 4.3 \\
\hline MASSACHUSETTS & 24.2 & 13 & 11.2 & 7.6 & 3.6 \\
\hline MICHIGAN & 23.9 & 13 & 10.9 & 8.9 & 2 \\
\hline MINNESOTA & 26.2 & 13 & 13.2 & 9.4 & 3.8 \\
\hline MISSISSIPPI & 24.4 & 13 & 11.4 & 8.8 & 2.6 \\
\hline MISSOURI & 23.1 & 13 & 10.1 & 6.4 & 3.7 \\
\hline MONTANA & 24.1 & 13 & 11.1 & 7.7 & 3.4 \\
\hline NEBRASKA & 24.9 & 13 & 11.9 & 6.7 & 5.2 \\
\hline NEVADA & 24.4 & 13 & 11.4 & 7.3 & 4.1 \\
\hline NEW HAMPSHIRE & 21.9 & 13 & 8.9 & 3.1 & 5.8 \\
\hline NEW JERSEY & 24.6 & 13 & 11.6 & 6.0 & 5.6 \\
\hline NEW MEXICO & 25.6 & 13 & 12.6 & 10.7 & 1.9 \\
\hline NEW YORK & 27.4 & 13 & 14.4 & 6.6 & 7.8 \\
\hline NORTH CAROLINA & 23.9 & 13 & 10.9 & 8.1 & 2.8 \\
\hline NORTH DAKOTA & 25.1 & 13 & 12.1 & 8.4 & 3.7 \\
\hline $\mathrm{OHIO}$ & 24.1 & 13 & 11.1 & 6.5 & 4.6 \\
\hline OKLAHOMA & 23.8 & 13 & 10.8 & 7.9 & 2.9 \\
\hline OREGON & 23.7 & 13 & 10.7 & 6.4 & 4.3 \\
\hline PENNSYLVANIA & 23.6 & 13 & 10.6 & 6.7 & 3.9 \\
\hline RHODE ISLAND & 24.5 & 13 & 11.5 & 7.0 & 4.5 \\
\hline SOUTH CAROLINA & 23.5 & 13 & 10.5 & 7.3 & 3.2 \\
\hline SOUTH DAKOTA & 23.1 & 13 & 10.1 & 5.4 & 4.7 \\
\hline TENNESSEE & 22 & 13 & 9 & 5.7 & 3.3 \\
\hline TEXAS & 23.3 & 13 & 10.3 & 5.4 & 4.9 \\
\hline UTAH & 25.1 & 13 & 12.1 & 8.3 & 3.8 \\
\hline VERMONT & 25.2 & 13 & 12.2 & 7.1 & 5.1 \\
\hline VIRGINIA & 22.8 & 13 & 9.8 & 6.0 & 3.8 \\
\hline WASHINGTON & 25 & 13 & 12 & 8.0 & 4 \\
\hline WEST VIRGINIA & 24.3 & 13 & 11.3 & 8.9 & 2.4 \\
\hline WISCONSIN & 26.3 & 13 & 13.3 & 8.9 & 4.4 \\
\hline WYOMING & 24.7 & 13 & 11.7 & 7.9 & 3.8 \\
\hline
\end{tabular}




\begin{tabular}{|c|c|c|}
\hline No. & REMI Sector & $\operatorname{SIC}(\mathbf{s})$ \\
\hline \multirow[t]{12}{*}{1} & Durables Manufacturing & $24,25,32-39$ \\
\hline & Lumber and wood products & 24 \\
\hline & Furniture and fixtures & 25 \\
\hline & Stone, clay, and glass products & 32 \\
\hline & Primary metals industries & 33 \\
\hline & Fabricated metal products & 34 \\
\hline & Machinery and computer equipment & 35 \\
\hline & Electronic equipment, except computer equipment & 36 \\
\hline & Motor vehicles and equipment & 371 \\
\hline & Transportation equipment excluding motor vehicles & Rest of 37 \\
\hline & Instruments and related products & 38 \\
\hline & Miscellaneous manufacturing industries & 39 \\
\hline \multirow[t]{11}{*}{2} & Nondurables Manufacturing & $20-23,26-31$ \\
\hline & Food and kindred products & 20 \\
\hline & Tobacco products & 21 \\
\hline & Textile mill products & 22 \\
\hline & Apparel and other textile products & 23 \\
\hline & Paper and allied products & 26 \\
\hline & Printing and publishing & 27 \\
\hline & Chemicals and allied products & 28 \\
\hline & Petroleum and coal products & 29 \\
\hline & Rubber and miscellaneous plastics products & 30 \\
\hline & Leather and leather products & 31 \\
\hline 3 & Mining & $10,12-14$ \\
\hline 4 & Construction & $15-17$ \\
\hline 5 & Transportation and Public Utilities & $40-42,44-49$ \\
\hline 6 & Finance, Insurance, and Real Estate & $60-65$ \\
\hline 7 & Retail Trade & $52-59$ \\
\hline 8 & Wholesale Trade & 50,51 \\
\hline 9 & Services & $70,72,73,75,76,78,84,86,87,89$ \\
\hline 10 & Agriculture, Forestry, and Fishing & $07,08,09$ \\
\hline 11 & State and Local Government & * \\
\hline 12 & Federal Government, Civilian & * \\
\hline 13 & Federal Government, Military & * \\
\hline 14 & Farm & 01,02 \\
\hline
\end{tabular}




\section{BLS and REMI Data}

The NIST Data Processor calculates return to capital—the "payment" to capital for every $\$ 1$ of production (sales) for each industry. A REMI input/output table shows composition of $\$ 1$ of production in terms of physical inputs (including fuel) and wages. The REMI input/output table is based on Bureau of Labor Statistics data, and may be provided to you in spreadsheet form directly from REMI.

Return to capital is the difference between $\$ 1$ and the cost of all the enumerated physical inputs and wages. The inverse of the amount of capital used per dollar of output is output per capital used. Output per capital used is the amount of output produced given the use of $\$ 1$ of capital. Note that this measure is not the same as the total value of the capital equipment-only the capital used.

A conservative estimate of yearly capital use may come from applying the depreciation rate for the industry to the total value of capital in the industry. Yearly depreciation can be thought of as how much of the capital asset was "used up" each year. A conservative assumption is that a machine must contribute to production (use) at least as much as the amount by which the machine depreciated.

The NIST Data Processor calculates depreciation, that is, the yearly decrease in value of the capital asset, using the estimated capital life for a manufacturing industry; these data are shown in Table A5 and are available from the Bureau of Labor Statistics[13]. Capital life is the number of years the capital is expected to last. A uniform yearly depreciation rate is assumed. Depreciation is the fraction (of the original value) by which the capital asset deceased in value. For example, a $\$ 1$ million capital asset which lasts for 20 years (a 5\% depreciation rate) is assumed to contribute at least $\$ 50$ thousand of capital input towards production (use) each year. 
Table A5. Depreciation Schedule for Capital Investment

\section{Industry}

Lumber and Wood Products (24)

Furniture and Fixtures (25)

Stone, Clay, and Glass Products (32)

Primary Metal Industries (33)

Fabricated Metal Products (34)

Industrial Machinery and Computer Equipment (35)

Electronics; Other Electric Equipment (36)

Motor Vehicles and Equipment (371)

Transportation Equipment (37)

Instruments and Related Products (38)

Misc. Manufacturing Industries (39)

Food and Kindred Products (20)

Tobacco Products (21)

Textile Mill Products (22)

Apparel; Other Textile Products (23)

Paper and Allied Products (26)

Printing and Publishing (27)

Chemicals and Allied Products (28)

Petroleum and Coal Products (29)

Rubber and Misc. Plastic Products (30)

Leather and Leather Products (31)

\begin{tabular}{|c|c|c|}
\hline & & $\begin{array}{l}\text { General } \\
\text { Industrial } \\
\text { Equipmer }\end{array}$ \\
\hline $\begin{array}{l}\text { Metal } \\
\text { W orking } \\
\text { Machinery }\end{array}$ & $\begin{array}{l}\text { Special } \\
\text { Industry } \\
\text { Machinery }\end{array}$ & $\begin{array}{l}\text { Including } \\
\text { Materials } \\
\text { Handling }\end{array}$ \\
\hline
\end{tabular}

\section{2}

15

15

17

24

33

30

31

17

17

21

17

21

25

26

20

19

20

19

20

27

17

19

Source: Bureau of Labor Statistics: http://www.bls.gov/mprcaptl.htm

The NIST Data Processor uses the average capital life for each industry. 


\section{Appendix B. NIST REMI Baseline-forecast Data File}

To retrieve REMI baseline-forecast data, simply go to the Results tab panel (Figure 12), select "Levels" from the Type box, and display the appropriate data.

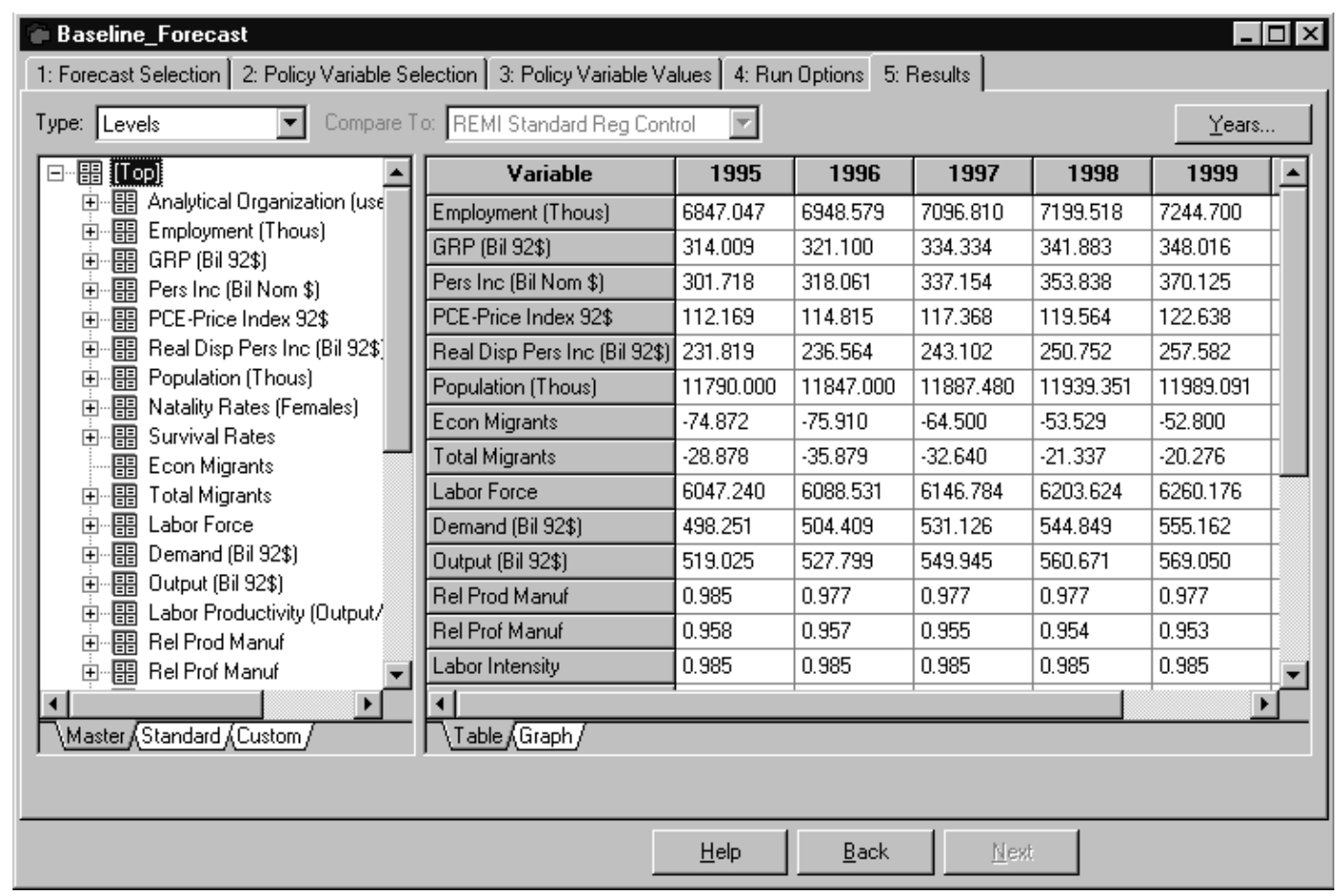

Figure B1. REMI Baseline Forecast

Use the Years button in the upper right corner to select the years for which you need data (unless otherwise indicated, provide data for the years 1995 through 2005). The following data should be provided to NIST, from the above screen in REMI:

- Price Index. The price indices are used by the NIST Data Processor to adjust all dollar denominated impacts in the Census Follow-up Data.

- Imports and demand, by two-digit-SIC manufacturing industry. The fraction of imports over demand in each industry and year are used to adjust client-reported changes in-state sales, jobs, and capital investment.

- Output and employment, by two-digit-SIC manufacturing industry. Dividing output by employment yields output per employee in each industry and year. This is used by the NIST Data Processor to determine the increase in production from new jobs.

\section{How to Provide the REMI Baseline-forecast Data to NIST}

To facilitate the quick use of the NIST Data Processor, NIST needs the REMI baseline forecast data in 
electronic-file format. Table B1 assists you in making these files. The first column tells you what data you are retrieving. The second column tells you where the data is located in the Results tab panel; you will need to select this exact label in REMI. The third column tells you what to name the data files.

\begin{tabular}{|c|c|c|}
\hline $\begin{array}{c}\text { Table B1. Data Needed From REM } \\
\text { Measure }\end{array}$ & $\begin{array}{l}\text { aseline Forecast } \\
\qquad \text { Location in Figure B1 }\end{array}$ & File Name \\
\hline PCE-Price Index 92\$ & 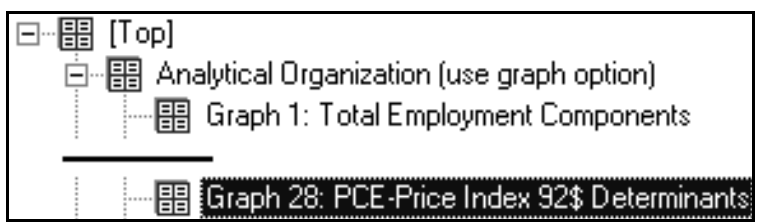 & price.txt \\
\hline Employment (Thous), Durables & 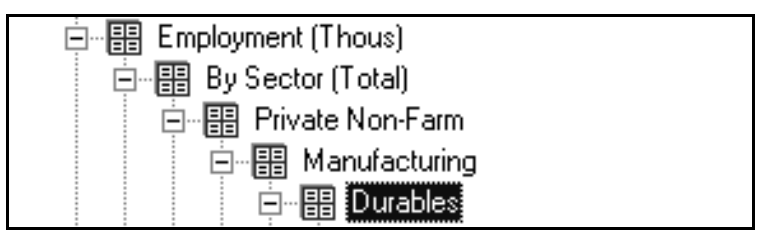 & employ1.txt \\
\hline Employment (Thous), Non-Durables & 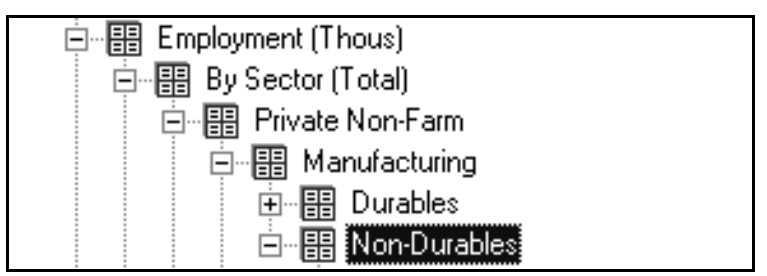 & employ2.txt \\
\hline Demand (Bil \$), Durables & 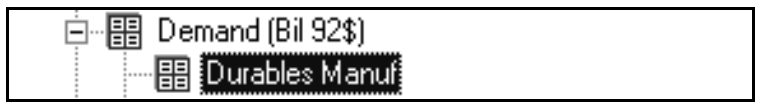 & demand1.txt \\
\hline Demand (Bil \$), Non-Durables & 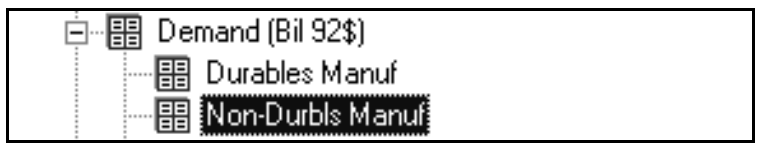 & demand2.txt \\
\hline Output (Bil \$), Durables & 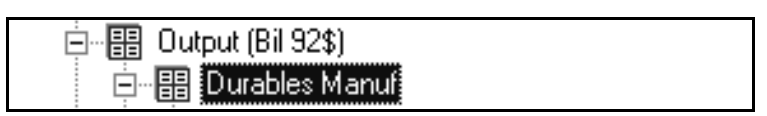 & output1.txt \\
\hline Output (Bil \$), Non-Durables & 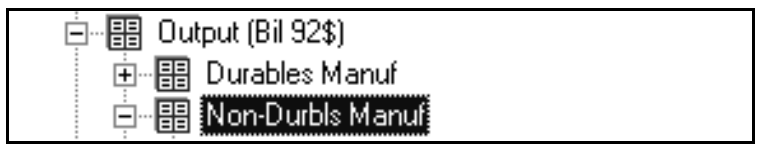 & output2.txt \\
\hline Imports (Bil \$), Durables & $\begin{array}{c}- \text { 腮 Imports (Bil 92\$) } \\
\text { 間 Durables Manuf) } \\
\end{array}$ & imports1.txt \\
\hline Imports (Bil \$), Non-Durables & $\begin{array}{c}\text { 間 Imports (Bil 92\$) } \\
\text { 間 Durables Manuf } \\
\text { 間 Non-Durbls Manuul }\end{array}$ & imports2.txt \\
\hline
\end{tabular}

The method of making each file is simple and consistent. Once you have expanded the data in the Results Tab to the appropriate level (shown in column 2), go to the task bar at the top of REMI, choose File, and then Print Preview. On the Print Preview window, there is a button labeled "Export." This is 
depicted in Figure B2.

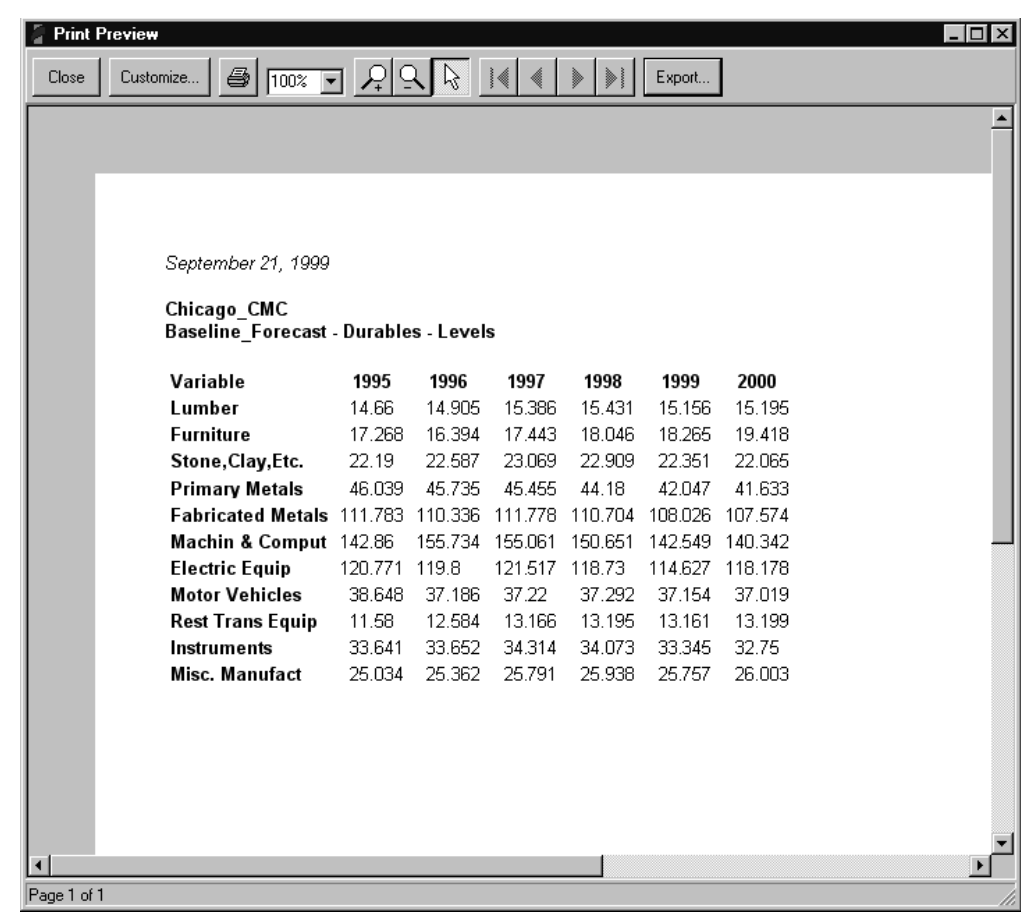

Figure B2. Print Preview Screen

Export the data to a tab-delimited text file; Figure B3 illustrates this step.

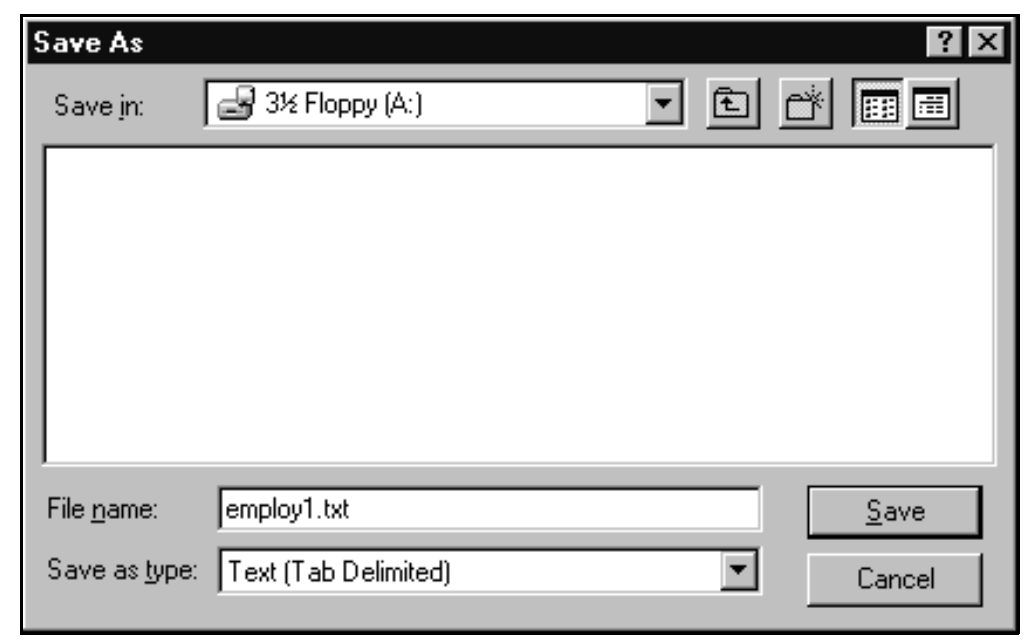

Figure B3. Saving the File

You will end up with nine files, one for each data type required. You may send them to NIST as an attachment to an email. The contact for this process is Hayden Brown, email address "hayden.brown@nist.gov." 


\section{References}

1. DRI McGraw-Hill (Macroeconomic Group), 24 Hartwell Avenue, Lexington, MA 02421.

2. Ehlen, Mark A. "The Economic Impact of Manufacturing Extension Centers," Economic Development Quarterly, forthcoming.

3. Ehlen, Mark A. Estimated Economic Impacts of the Advanced Technology Program's Flow-Control Machining Project: Early Applications in the Automobile Industry. NISTIR 6373. Gaithersburg, MD: National Institute of Standards and Technology, 1999.

4. Ehlen, Mark A, and Weber, Stephen W. Estimating Economic Impacts of Government Technology Programs: Manufacturing Studies Using the REMI Model. NISTIR 6107. Gaithersburg, MD: National Institute of Standards and Technology, 1997.

5. Federation of Tax Administrators. "1996 State \& Local Revenues as a Percentage of Personal Income," Washington, D.C., 1998.

6. Federation of Tax Administrators. “1998 State Tax Revenue,” Washington, D.C., 1998.

7. Minnesota IMPLAN Group, Inc. 1725 Tower Drive West Suite 140, Stillwater, MN 55082.

8. Manufacturing Extension Partnership. Census Follow-up Survey, 1995-1999.

9. Regional Economic Modeling, Incorporated. REMI Policy Insight, Version 1.1 (software). Amherst, MA, 1999.

10. Thompson, Chris. A Guide for Communicating Impact, Version 2.0, Manufacturing Extension Partnership, National Institute of Standards and Technology, July 1999.

11. Treyz, G.I. Regional Economic Modeling (Norwell, Massachusetts: Kluwer Academic Publishers), 1993, p. 91.

12. U.S. Bureau of Economic Analysis. Regional Input-Output Multipliers RIMS II, http:/www.bea.doc.gov/bea/regional/rims/, 1999.

13. U.S. Bureau of Labor Statistics. Revisions to Capital Inputs for the BLS Multifactor Productivity Measures, http://www.bls.gov/mprcaptl.htm, 1999.

14. WEFA. 800 Baldwin Tower, Eddystone, PA 19022. 